OPEN ACCESS

Edited by:

Michał Tomczyk,

Medical University of Bialystok, Poland

Reviewed by:

Chuying Chen,

Jiangxi Agricultural University, China

Jen-Tsung Chen,

National University of Kaohsiung,

Taiwan

*Correspondence:

Jialin Qu

jialin_qu@126.com

Aijing Leng

L18098877517@163.com

${ }^{\dagger}$ These authors have contributed equally to this work

Specialty section:

This article was submitted to

Ethnopharmacology,

a section of the journal

Frontiers in Pharmacology

Received: 04 August 2021

Accepted: 04 October 2021

Published: 01 November 2021

Citation:

Li X, Chen C, Leng A and Qu J (2021)

Advances in the Extraction,

Purification, Structural Characteristics and Biological Activities of

Eleutherococcus senticosus

Polysaccharides: A Promising Medicinal and Edible Resource With

Development Value.

Front. Pharmacol. 12:753007.

doi: 10.3389/fphar.2021.753007

\section{Advances in the Extraction, Purification, Structural Characteristics and Biological Activities of Eleutherococcus senticosus Polysaccharides: A Promising Medicinal and Edible Resource With Development Value}

Xiaojie $\mathrm{Li}^{1,2 \dagger}$, Cai Chen ${ }^{1,3 \dagger}$, Aijing Leng ${ }^{3,4 *}$ and Jialin $Q u^{1,3 *}$

${ }^{1}$ Laboratory of Integrative Medicine, The First Affiliated Hospital of Dalian Medical University, Dalian, China, ${ }^{2}$ Institute (College) of Pharmacy, Dalian Medical University, Dalian, China, ${ }^{3}$ Institute (College) of Integrative Medicine, Dalian Medical University, Dalian, China, ${ }^{4}$ Department of Traditional Chinese Medicine. The First Affiliated Hospital of Dalian Medical University, Dalian, China

In recent years, natural polysaccharides have received growing attention and interest in view of their values in food, medical, cosmetics and other fields. Eleutherococcus senticosus (E. senticosus) is a medicine and food homologous plant that possess antitumor, anti-inflammatory, central nervous system and cardiovascular protection, antiradiation, enhancement of human microcirculation, improvement of physical fatigue effects, mainly based on lignans, flavonoids and coumarin types. E. senticosus polysaccharides (ESPS), act as a kind of polysaccharide extracted and isolated from the root and rhizome of $E$. senticosus, have been found in many applications of medicine and food for their unique biological activity. Nevertheless, the existing studies are mostly concerned with small molecules of $E$. senticosus, less attention is paid to polysaccharides. Moreover, the types and structural characterization of ESPS reported in existing literature were also not summarized. In this paper, the research progress of ESPS is reviewed from the aspects of extraction, separation, structural characterization and biological activity, future perspectives from points of efficient extraction, resource utilization and quality control standards were also proposed, which provide reference for the further development and utilization of ESPS.

Keywords: extraction, purification, structure, bioactivities, Eleutherococcus senticosus polysaccharides (ESPS, )

\section{HIGHLIGHTS}

- The extraction and purification techniques of Eleutherococcus senticosus polysaccharides were summarized.

- Types and structural characterization of Eleutherococcus senticosus polysaccharides isolated and purified at present were preliminarily discussed.

- The modern pharmacological research and biological activity of Eleutherococcus senticosus polysaccharides were summarized, and its application prospect was proposed. 


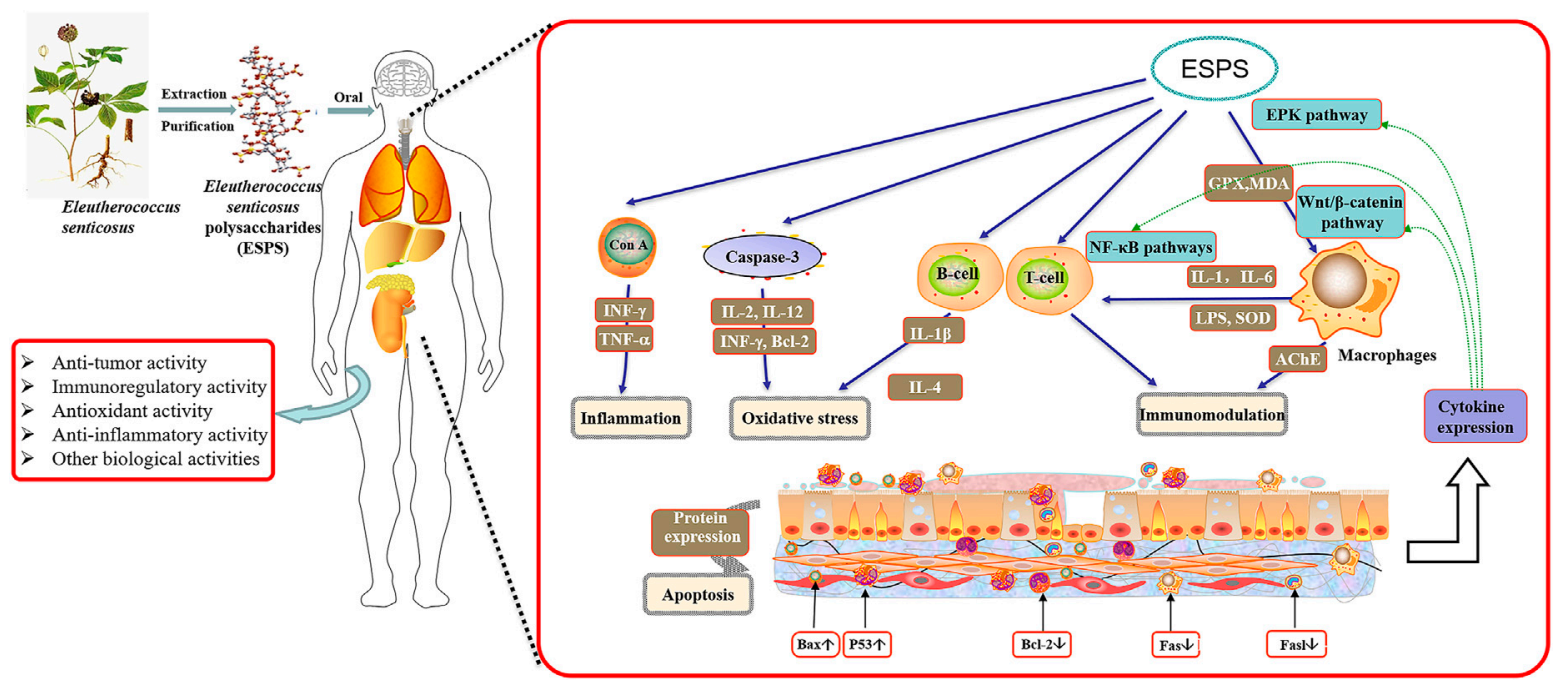

GRAPHICAL ABSTRACT |

\section{INTRODUCTION}

Eleutherococcus senticosus, commonly known as "Ci-wu-jia" or "Acanthopanax senticosus", is botanically from the dried root and rhizome or stem of Eleutherococcus senticosus (Rupr. et Maxim.) Maxim [syn. Acanthopanax senticosus (Rupr. and Maxim.) Harms] belong to the Araliaceae. It is a medicine and food homologous plant that is widely distributed in northeast China, which contains multi-kinds of nutrients and components. Among variety of active ingredients, flavonoids (quercetin, hyperoside, quercetin, rutin, etc.), coumarins (isofraxidin, scopolamine, etc), lignans (ferulic acid glucoside, eleutheroside, carotin, syringin, etc.,) (Lee et al., 2012) played an important role in its activities. Moreover, some trace elements such as $\mathrm{Ca}, \mathrm{P}, \mathrm{Mg}, \mathrm{Fe}$, a variety of amino acids and polysaccharides also play a role in mediating the immune function of the body (Liu, 2010), antioxidant, anti-tumor, antiinflammatory, central nervous system and cardiovascular protection, anti-radiation, enhancement of human microcirculation, improvement of physical fatigue, etc., (Luan, 2012; Pan, 2019a). As a medicinal and food homologous plant, various products such as oral liquid, tea, capsule preparation, wine of $E$. senticosus have been developed and commercialized, and favored by those who pay attention to health. The products of E. senticosus are listed in Figure 1.

In recent years, polysaccharides have demonstrated good therapeutic effects against tumors, hyperlipemia, diabetes and hypertensive diseases (Shen et al., 1991; Duan, 2015). The development and utilization of polysaccharides have also become a hot spot. E. senticosus polysaccharides (ESPS) are an important biologically active ingredient extracted from the roots and rhizomes of E. senticosus. The content of alkaline polysaccharides in E. senticosus is about $2-8 \%$, and that of the water-soluble polysaccharides is $2.3-5.7 \%$ (Gao, 2019). Studies had shown that ESPS possessed immunoenhancement (Xu et al.,
2005), anti-tumor (Hao and Nan, 2013), anti-virus (Zhou, 2018), anti-fatigue, anti-oxidation, anti-diabetes (Fu et al., 2012), hepatoprotective, and other biological activities (Chen and Huang, 2018; Ganesan and Xu, 2019; Zeng et al., 2019), which prompts the huge application and development potential of ESPS. In this paper, the extraction and purification process and structure characterization of ESPS were systematically introduced, and the studies on biological activities of ESPS were further reviewed in order to expand the application of ESPS.

\section{EXTRACTION AND PURIFICATION}

\section{Extraction of Crude Polysaccharides Hot Water Extraction}

Polysaccharides are a category of substances with higher polarity, higher water soluble and insoluble in $\mathrm{EtOH}$. Because of the nature of polysaccharides, hot water extraction in combination with EtOH-precipitated has been commonly used in laboratories and industrial production. EtOH-precipitated polysaccharides are suitable for almost all water-soluble polysaccharides. The principal principle is to separate the polysaccharides by reducing the dielectric constant of the aqueous solution to dehydrate the polysaccharides for precipitation. There are several ways to extract ESPS (Table 1). Feng et al. used a single factor test to optimize the extraction conditions of ESPS and obtained the optimal condition: pulverization degree above 80 mesh, solute extraction $50 \% \mathrm{EtOH}$, extraction $\mathrm{pH}=6$, soaking for $2 \mathrm{~h}$, degreasing treatment with petroleum ether. Under these conditions, the extraction yield of crude ESPS could reach $3.27 \pm 0.07 \%$ (Feng, 2016). An orthogonal experiment was developed from the experimental data in order to predict the ESPS yield by Cheng, the optimal condition was found to be: extraction temperature $80^{\circ} \mathrm{C}$, extraction once, time of $150 \mathrm{~min}$ and solid-liquid ratio of $1: 20 \mathrm{~g} / \mathrm{ml}$ with a maximum pectin yield 
TABLE 1 | Summary of the extraction process of ESPS.

\begin{tabular}{|c|c|c|c|c|c|c|}
\hline Method & Pros & Cons & Optimization Factors & Optimization Results & ESPS Content & References \\
\hline $\begin{array}{l}\text { Hot water } \\
\text { extraction }\end{array}$ & $\begin{array}{l}\text { The production cycle is } \\
\text { short, the experiment } \\
\text { cost is low, experiment } \\
\text { operation is simple and } \\
\text { the degree of damage to } \\
\text { the structure of the } \\
\text { extract is small. }\end{array}$ & $\begin{array}{l}\text { Part of the protein will be } \\
\text { extracted and protein must } \\
\text { be removed; low selectivity, } \\
\text { low extraction rate. }\end{array}$ & $\begin{array}{l}\text { Material/liquid, extraction } \\
\text { time, times, temperature, } \\
\text { alcohol precipitation } \\
\text { temperature, time, } \mathrm{pH}\end{array}$ & $\begin{array}{l}90^{\circ} \mathrm{C}, 150 \mathrm{~min} \text {, material/ } \\
\text { liquid } 1: 18 \text {, extraction twice; } \\
\text { alcohol precipitation } \\
\text { condition }-20^{\circ} \mathrm{C}, 36 \mathrm{~h} \text {, } \\
\text { ethanol extractant ratio } 4 \text { : } \\
1, \mathrm{pH}=7\end{array}$ & $263.3 \mathrm{mg} / \mathrm{ml}$ & Zhai (2007) \\
\hline- & - & - & $\begin{array}{l}\text { Extraction temperature, } \\
\text { time, material/liquid I, } \\
\text { times }\end{array}$ & $\begin{array}{l}80^{\circ} \mathrm{C}, 150 \mathrm{~min} \text {, material/ } \\
\text { liquid } 1: 20 \text {, extract once } \\
\text { extraction time> extraction } \\
\text { temperature }>\text { extraction } \\
\text { times }>\text { material/liquid }\end{array}$ & $23.21 \mathrm{mg} / \mathrm{g}$ & Chen (2011a) \\
\hline- & - & - & $\begin{array}{l}\text { Material/liquid, extraction } \\
\text { time, temperature, times }\end{array}$ & $\begin{array}{l}90^{\circ} \mathrm{C}, 2.5 \mathrm{~h} \text {, material/liquid } 1: \\
25(\mathrm{~g} / \mathrm{mL}) \text {, extract } 3 \text { times. }\end{array}$ & $23.95 \mathrm{mg} / \mathrm{g}$ & Chen (2015a) \\
\hline- & - & - & $\begin{array}{l}\text { E. senticosus } \\
\text { pulverization degree, } \\
\text { extraction solute, } \mathrm{pH} \text {, } \\
\text { soaking time degreasing } \\
\text { solvent }\end{array}$ & $\begin{array}{l}\text { degree of pulverization: }>80 \\
\text { meshes, solute is extracted } \\
\text { by } 50 \% \text { ethanol, } \mathrm{pH}=6 \\
\text { (petroleum ether degreasing } \\
\text { treatment soaking } 2 \mathrm{~h}\end{array}$ & $\begin{array}{c}3.27 \pm 0.07 \% \\
\quad(n=3)\end{array}$ & Feng (2016) \\
\hline- & - & - & $\begin{array}{l}\text { Extraction parts (rhizome, } \\
\text { leaves, fruits) extraction } \\
\text { time, temperature, } \\
\text { alcohol concentration, } \\
\text { material/liquid }\end{array}$ & $\begin{array}{l}95^{\circ} \mathrm{C}, 116 \text { min, material/ } \\
\text { liquid } 31: 1 \text { best extraction } \\
\text { part fruit, alcohol } \\
\text { concentration } 85 \%\end{array}$ & $13.21 \%$ & Shen (2017) \\
\hline- & - & - & $\begin{array}{l}\text { Extraction temperature, } \\
\text { time, material / liquid }\end{array}$ & $\begin{array}{l}80^{\circ} \mathrm{C}, 1.5 \mathrm{~h}, \text { material/liquid } \\
1: 21\end{array}$ & $10.14 \%$ & Yu (2019) \\
\hline \multirow[t]{2}{*}{$\begin{array}{l}\text { Ultrasonic } \\
\text { extraction }\end{array}$} & \multirow[t]{2}{*}{$\begin{array}{l}\text { More efficient, faster, high } \\
\text { extraction yield, low } \\
\text { energy consumption }\end{array}$} & $\begin{array}{l}\text { Ultrasound will damage the } \\
\text { structure of polysaccharides, } \\
\text { resulting in difficulty in }\end{array}$ & $\begin{array}{l}\text { Extraction temperature, } \\
\text { material/liquid, time, } \\
\text { ultrasonic power }\end{array}$ & $\begin{array}{l}58^{\circ} \mathrm{C}, 73 \mathrm{~min}, \text { material/liquid } \\
1: 25 ; \text { ultrasonic power } 85 \mathrm{~W}\end{array}$ & $\begin{array}{c}1.532 \pm 0.037 \% \\
(n=3)\end{array}$ & $\begin{array}{l}\text { Chen et al. } \\
\text { (2018) }\end{array}$ \\
\hline & & $\begin{array}{l}\text { separation and difficult to } \\
\text { apply to industrial production }\end{array}$ & $\begin{array}{l}\text { Ultrasonic power, } \\
\text { material/liquid, extraction } \\
\text { temperature, time }\end{array}$ & $\begin{array}{l}57^{\circ} \mathrm{C}, 42 \mathrm{~min}, \text { material/liquid } \\
1: 40 \mathrm{~g} / \mathrm{mL} \text { ultrasonic } \\
\text { power } 90 \mathrm{~W}\end{array}$ & $3.86 \%$ & Chen (2015b) \\
\hline $\begin{array}{l}\text { Microwave } \\
\text { extraction }\end{array}$ & $\begin{array}{l}\text { Strong penetration, } \\
\text { uniform and fast heating, } \\
\text { high selectivity. }\end{array}$ & $\begin{array}{l}\text { Polysaccharides often } \\
\text { contain some pigments, so } \\
\text { they need to be decolorized. }\end{array}$ & - & $\begin{array}{l}\text { It was the first time to extract } \\
\text { ESPS using microwave } \\
\text { technology and determine its } \\
\text { content. }\end{array}$ & $5.01 \%$ & $\begin{array}{l}\text { Li and Liu } \\
\text { (2003) }\end{array}$ \\
\hline- & - & - & $\begin{array}{l}\text { Extraction time, } \\
\text { microwave power, } \\
\text { material/liquid }\end{array}$ & $\begin{array}{l}22.5 \mathrm{~min}, \text { material/liquid 1:25 } \\
22.5 \mathrm{~min} \text {, material/liquid 1:25 }\end{array}$ & $\begin{aligned} 1.52 \% & \pm 0.09 \% \\
(n & =3)\end{aligned}$ & $\begin{array}{l}\text { Zhang and } \\
\text { Guo (2015) }\end{array}$ \\
\hline $\begin{array}{l}\text { Alkaline } \\
\text { extraction }\end{array}$ & $\begin{array}{l}\text { Higher total glucose } \\
\text { content }\end{array}$ & $\begin{array}{l}\text { The yield of polysaccharide } \\
\text { was slightly lower, and it will } \\
\text { damage the structure of acid } \\
\text { polysaccharide and neutral } \\
\text { polysaccharide }\end{array}$ & $\begin{array}{l}\text { Alkali concentration, } \\
\text { material/alkali ratio, alkali } \\
\text { extraction time }\end{array}$ & $\begin{array}{l}\text { Alkali extraction } \\
\text { time>material-alkali } \\
\text { ratio>alkali concentration } \\
10 \mathrm{~h} \text {, material/alkali 1:16. } \\
\text { alkali concentration } 4 \% \text {, }\end{array}$ & $5.70 \%$ & Wang (2006) \\
\hline- & - & - & $\begin{array}{l}\text { Graded alcohol } \\
\text { precipitation, step-by- } \\
\text { step alcohol precipitation }\end{array}$ & $\begin{array}{l}\text { Used step-by-step alcohol } \\
\text { precipitation method, more } \\
\text { and higher content of } \\
\text { polysaccharides can be } \\
\text { obtained }\end{array}$ & $6.01 \%$ & Li (2019) \\
\hline
\end{tabular}

(23.3 $\mathrm{mg} \mathrm{g}^{-1}$ ) (Chen, 2011a). Based on the single factor test, some researches adopted the Box-Behnken center combination design test and response surface method (RSM) to compare rhizomes, fruits, and leaves, and finally determined that the fruit was the best extraction part. This technique gives a maximal yield of $13.21 \%$ for material-liquid ratio of $31: 1$ in $116 \mathrm{~min}$, extraction temperature $95^{\circ} \mathrm{C}$ (Shen, 2017). Some scholars also investigated the drying method and found that the freeze-drying method was better than the spray-drying method (Zhang and Sun, 2005).

However, the hot water extraction method will introduce some impurities like protein, which needs to be removed. Sevag reagent, trifluoro trichloroethane, trichloroacetic acid, anion and cation exchange resin and the enzymatic hydrolysis are the commonly used mediums. In ESPS literature, protein is mostly removed by the Sevag method (Jiao, 2008; Li, 2019). Wang et al. compared the deproteinization effects of Sevag, trichloroacetic acid (TCA)-Sevag, chitosan coagulation and enzyme on ESPS. The results showed that the protein removal rate: enzyme $93.1 \%$ = chitosan coagulation 93.1\% > TCA-Sevag $83 \%>$ Sevag 28\%, polysaccharide loss rate: chitosan coagulation $47 \%>$ TCA-Sevag $43 \%>$ Sevag $18 \%>$ enzyme $7 \%$. Results indicated that enzyme deproteinization has the best effect (Wang, 2009). 

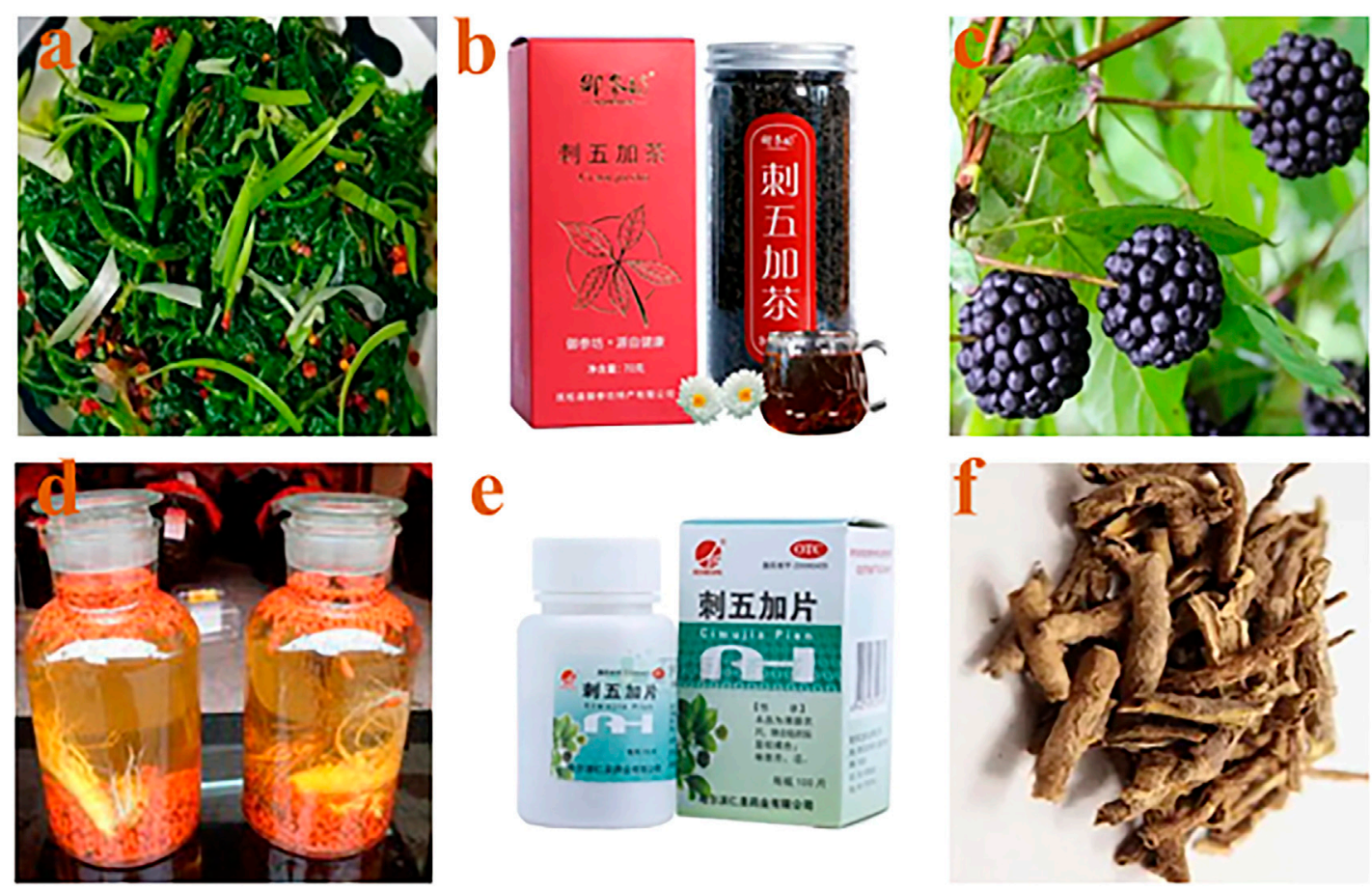

FIGURE 1 | Eleutherococcus senticosus. Salad from leaves (A); tea (B); pulp (C); wine (D); tablets (E); cortex (F).

\section{Ultrasound-Assisted Extraction (UAE)}

The ultrasound-assisted extraction (UAE) method were employed for increasing the movement frequency and speed of macromolecules, strengthening the solvent penetration ability, and shortening the extraction period of polysaccharides by ultrasonic waves (Cui, 2012). In some experiments, the RSM was used to optimize the extraction of ESPS by ultrasound-assisted extraction (UAE), by which the optimum levels of the parameters were obtained as follows: extraction temperature $58^{\circ} \mathrm{C}$, extraction time $73 \mathrm{~min}$, liquid/solid ratio 25:1, ultrasonic power $85 \mathrm{~W}$ (Chen et al., 2018). However, the extraction time should not be too long because ultrasound has a mechanical shearing effect, which may damage the structure of ESPS. Moreover, the UAE method is difficult to be widely applied in the field of industrial production in view of the limitations of the instruments.

\section{Microwave Extraction}

Water molecules in the cell are rapidly heated and pressurized under microwave due to its strong penetrating power, which increased the extraction rate by breakage of cell wall and release of intracellular polysaccharides into the extract.

$\mathrm{Li}$ et al. removed fat-soluble impurities and interfering components gradually with petroleum ether, ether and $\mathrm{EtOH}$ and then ectracted E. senticosus crude polysaccharide by microwave technology (Li and Liu, 2003). Zhang et al. used the RSM based on Box-Behnken design to optimize the extraction of ESPS from three aspects of the microwave power, microwave processing time and material-to-liquid ratio parameters. The results showed that microwave extraction
$22.5 \mathrm{~min}$, microwave power $450 \mathrm{~W}$, material-liquid ratio $1: 25$ $\left(\mathrm{g} \cdot \mathrm{ml}^{-1}\right.$ ) achieved the best performance (Zhang and Guo, 2015). Furthermore, microwave extraction of ESPS often requires depigmentation. Ion exchange, adsorption, oxidation and metal complexation are common methods for subsequent depigmentation.

\section{Alkali-Extraction}

Polysaccharides could be divided into acidic, alkaline and neutral polysaccharides, which can be extracted by adjusting the acidity and alkalinity like some small molecule compounds. For example, Jiang et al. extracted lemon polysaccharides under alkaline conditions with an extraction rate of $8.81 \%$ (Jiang et al., 2017), Li et al. used alkaline leaching method to optimize the extraction of acidic Tuckahoe polysaccharides, the extraction rate was increased to $78.5 \%$ (li, 2018). Similarly, corn silk polysaccharide was comparatively extracted by acid extraction and water under the same experimental conditions. The extraction rate $33.36 \%$ obtained by acid was higher than the water extraction (7.44\%) (Li and Zhou, 2020). Thus, polysaccharides could also be extracted by the acid and alkaline leaching method due to their hydrolysis. However, little related literature on extracting ESPS were obtained in view of the fact that the acid-base method may destroy the structure of the active polysaccharides.

Li et al. compared the extraction of ESPS with water extraction and alkali-extraction. The yield of crude polysaccharides from water extraction and EtOH precipitation was 20.8\%, and total carbohydrate content in which was $5.19 \%$. Alternatively, the value 


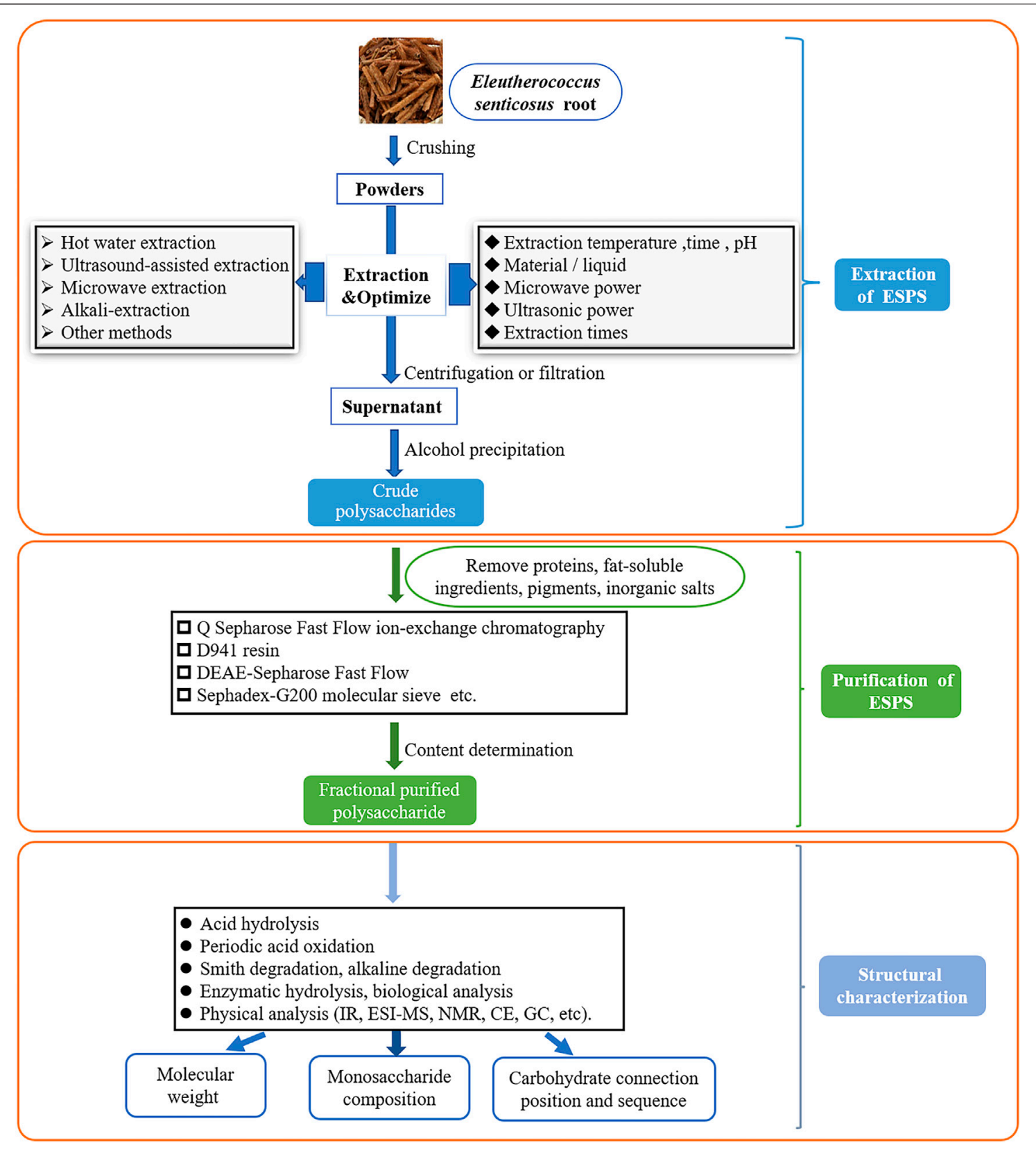

FIGURE 2 | Schematic diagram of extraction, purification and structural characterization of ESPS.

obtained from alkali-extraction and $\mathrm{EtOH}$ precipitation were 18.31 and $6.01 \%$, respectively $(\mathrm{Li}, 2019)$.

\section{Other Methods}

Aside from the common technologies mentioned above, enzymatic hydrolysis, supercritical fluid extraction (SFE) (Wei, 2018), enzyme-microwave-ultrasonic-assisted extraction (Yin et al., 2018) were also employed in the extraction of plant polysaccharides. However, these methods have not been applied to the ESPS extraction at present, which needs further research. Moreover, the crude polysaccharides extracted by above methods need to remove proteins, fat-soluble ingredients, pigments, inorganic salts and other small molecule impurities before subsequent tests. Figure 2 summarized the diagram of extraction, purification and structural characterization of ESPS.

\section{Purification of Eleutherococcus Senticosus Polysaccharides}

Polysaccharides in medicinal materials often coexist with other active ingredients. The separation and purification of homogeneous polysaccharide from crude polysaccharides was usually achieved by EtOH precipitation according to the solubility differences in EtOH. Normally, EtOH precipitation 


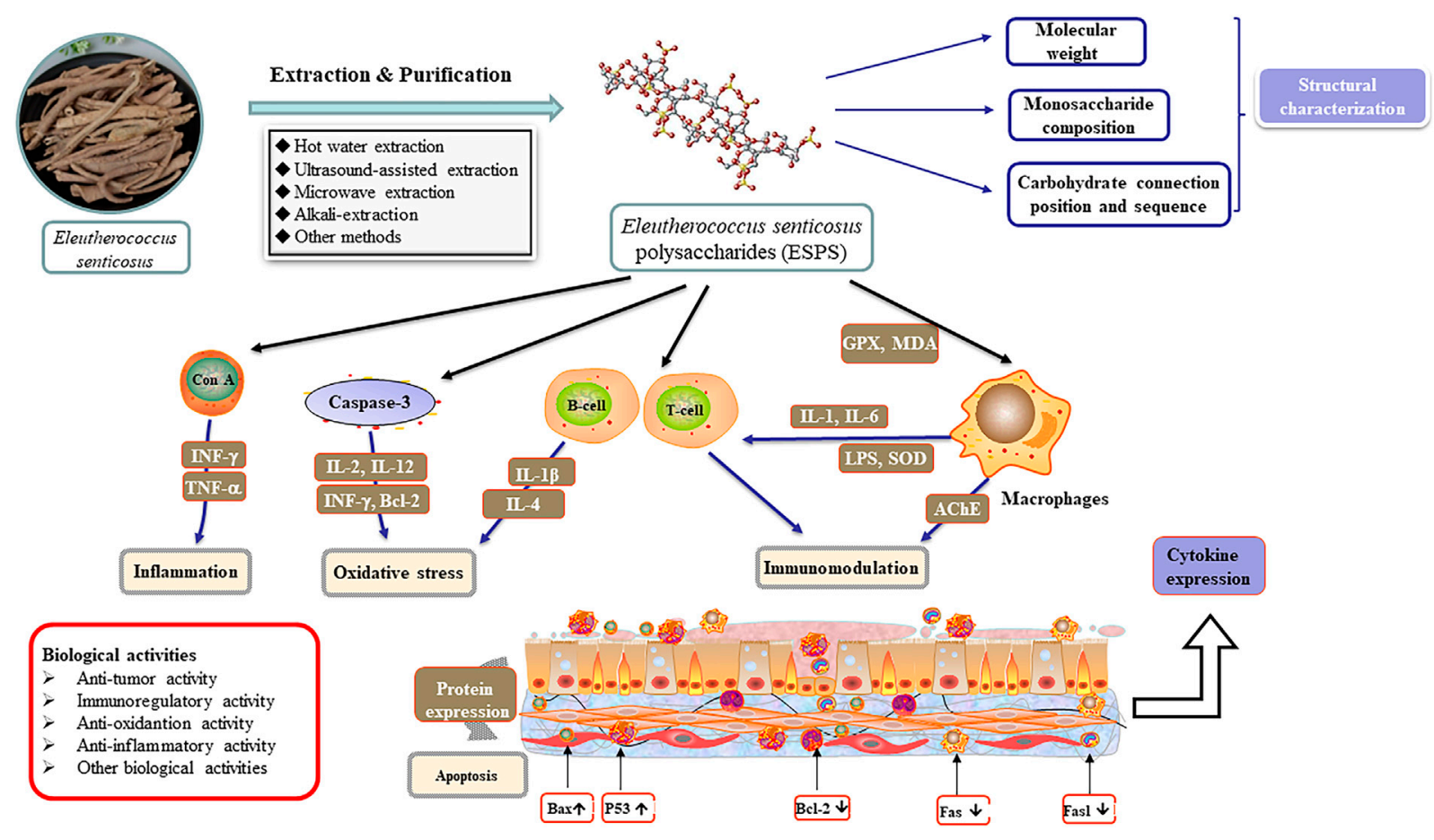

FIGURE 3 | Schematic diagram of biological activity mechanism of ESPS.

could be divided into step-alcohol-sinking and graded-alcoholsinking, respectively. Related experiments showed that the purification performance of ESPS by step-alcohol-sinking performed more perfect in view of the higher content (Li, 2019). Besides, the concentration of alcohol in the gradedalcohol-sinking method would also affect the biological activity of ESPS. Li et al. compared the immune enhancement effects of ESPS obtained from 20, 40, and 60\% alcohol precipitations. After comparison, ESPS obtained from 40\% EtOH-precipitated exhibited better resistance to the splenic lymphocyte proliferation induced by ConA and LPS in a dose-dependent manner (Li, 2020).

In recent years, new materials and technologies have been increasingly applied in the separation and purification of polysaccharides accompanied by the rapid development of the science and technology. Among which, ion exchange chromatography has been used for the preparation of various types of components of traditional Chinese medicine in view of their advantages of good separation effect, fast separation speed, wide application range, and simple operation. Usually, diethylaminoethyl (DEAE)-cellulose is first used as an exchange agent to purify the polysaccharide to be acidic or neutral. The separated one was further purified by Sephadex gel according to the difference in molecular size. Based on this principle, scholars have developed different classification and types of fillers to achieve the systematic separation of polysaccharides with different properties. For example, Wang et al. employed Q Sepharose Fast Flow ion-exchange chromatography column to purify three kinds of ESPS,NASC1, ASH-1 and ASA-1 that extracted by cold alkali, hot alkali and acid solutions, respectively (Wang, 2006). Bai et al. classified the ESPS from the rhizomes of E. senticosus into neutral ASPN and acidic ASPA-1 and ASPA-2 by DEAE-cellulose column. Subsequently, Sepharose CL-6B was further used to separate ASPA-1 into two uniform grades, namely ASPA-1-A and ASPA-1-B (Bai, 2015). Similarly, Zhai et al. adopted D941 resin, DEAE-Sepharose Fast Flow to chromatograph the crude polysaccharide and then used Sephadex-G200 molecular sieve to obtain the purified neutral and acidic polysaccharide As-1 and As-2, respectively (Zhai, 2007).

\section{Content Determination}

Content determination is an important procedure to control and evaluate the quality of polysaccharide products. Phenol-sulfuric acid and anthrone-sulfuric acid methods were the most commonly used ones. The principle is that polysaccharides are hydrolyzed into monosaccharides and further dehydrated to furfural or carboxymethyl furfural due to the concentrated sulfuric acid. Subsequently, phenol or anthraquinone can undergo condensation reaction with furfural derivatives to produce orange-yellow and blue-green compounds. Within $100-200 \mathrm{mg}$, the color depth increases with the increase of polysaccharide content, which can be determined by colorimetry. The compound produced by the phenol-sulfuric acid method has a maximum absorption peak at a wavelength of $490 \mathrm{~nm}$, so the absorbance of the sample is measured at $\lambda=$ $490 \mathrm{~nm}$ (Bai, 2015).

A study compared the phenol-sulfuric acid and the anthronesulfuric acid methods for the determination of ESPS content and found that the results of the two methods were similar, but the 
TABLE 2 | Structural characterization of polysaccharides isolated from the different parts of Eleutherococcus senticosus.

\begin{tabular}{|c|c|c|c|c|c|c|c|}
\hline No & $\begin{array}{l}\text { Compound } \\
\text { Name }\end{array}$ & $\begin{array}{l}\text { Medical } \\
\text { Parts }\end{array}$ & Monosaccharide Composition $^{a}$ & $\begin{array}{l}\text { Main chain } \\
\text { composition/ } \\
\text { structural domain }\end{array}$ & Branch composition & M.W. (KDa) & Reference \\
\hline 1 & PES-A & Root & Glc: Gal: Ara $=3 \cdot 3: 2: 1$ & - & - & 7 & Xu (1983) \\
\hline- & PES-B & Root & - & - & - & 76 & Xu (1983) \\
\hline- & PES-W & Root & - & - & - & - & Xu (1983) \\
\hline 2 & As-II & Root & Glc & - & - & 150 & wang (1986) \\
\hline- & As-III & Root & Ara: Xyl:4-O-methyl-D-GlcA =1:11:1 & - & - & 30 & wang (1986) \\
\hline 3 & AS-2 & Root & Ara: Xyl: Rha: Gal: Glc =1.6:1.2:1.8:1.0:3.6 & $\begin{array}{l}\beta-(1 \rightarrow 3)-G \mid c \\
\beta-(1 \rightarrow 4)-G \mid c\end{array}$ & $\begin{array}{c}(1 \rightarrow 4)-\text { Rha, }(1 \rightarrow 6)-\text { Gal, } \\
(1 \rightarrow 3)-\text { Gal, }(1 \rightarrow 6)-\text { Glc }\end{array}$ & 78 & $\begin{array}{l}\text { Zhang et al. } \\
(1993)\end{array}$ \\
\hline 4 & ASP & Root & - & - & - & - & $\begin{array}{l}\text { Han et al. } \\
(2003)\end{array}$ \\
\hline 5 & ASC-1 & Root & - & - & - & - & $\begin{array}{l}\text { Wang et al. } \\
(2006)\end{array}$ \\
\hline- & ASC-2 & Root & Rha: Ara: Xyl: Glc: Gal & - & - & - & $\begin{array}{l}\text { Wang et al. } \\
(2006)\end{array}$ \\
\hline- & ASC-2C & Root & - & - & - & 17 & $\begin{array}{l}\text { Wang et al. } \\
(2006)\end{array}$ \\
\hline- & ASC-2S & Root & - & - & - & 11 & $\begin{array}{l}\text { Wang et al. } \\
(2006)\end{array}$ \\
\hline 6 & ASC-1P2B & Root & Xyl & - & - & - & $\begin{array}{l}\text { Wang et al. } \\
(2006)\end{array}$ \\
\hline 7 & $\mathrm{ASH}-1$ & Root & - & - & - & - & $\begin{array}{l}\text { Wang et al. } \\
(2006)\end{array}$ \\
\hline- & $\mathrm{ASH}-1 \mathrm{P3}$ & Root & Rha: Ara: Xyl: Man: Glc: Gal & - & - & - & Wang et al. \\
\hline 8 & ASA-1 & Root & - & - & - & 12 & $\begin{array}{l}\text { Wang et al. } \\
(2006)\end{array}$ \\
\hline- & ASA-2 & Root & - & - & - & - & $\begin{array}{l}\text { Wang et al. } \\
(2006)\end{array}$ \\
\hline 9 & ASA-1P3A & Root & Glc: Xyl: Gal= 22.4:5.2:1 & $(1 \rightarrow 6)-G l c$ & $\begin{array}{l}(1 \rightarrow 4)-\text { Glc, }(1 \rightarrow 3) / \\
(1 \rightarrow 4)-X y l\end{array}$ & 38.3 & $\begin{array}{l}\text { Wang et al. } \\
\text { (2006) }\end{array}$ \\
\hline- & ASA-1P3B & Root & Glc: Xyl: Gal =7.6:19.4:1 & $(1 \rightarrow 2)-G l c,(1 \rightarrow 4)-X y l$ & $\begin{array}{l}(1 \rightarrow 3)-X y l,(1 \rightarrow 2) \\
(1 \rightarrow 4),(1 \rightarrow 6)-G l c\end{array}$ & 7.2 & $\begin{array}{l}\text { Wang et al. } \\
(2006)\end{array}$ \\
\hline 10 & ASP-2-1 & Leaf & $\begin{array}{l}\text { Rha: Xyl: Glc: Man: Ara: Gal: GlcA =7.45: } \\
\text { 18.63:25.15:0.93:8.35:2.79:5.69 }\end{array}$ & - & - & 14.6 & Chen (2011b) \\
\hline 11 & ESPS & Root & $\begin{array}{l}\text { Man: Rha: GlcA: GalA: Glc: Gal: Xyl: Ara: } \\
\text { Fuc=1.5:13.6:0.6:14.9:17.1:24.2:11.6: } \\
\text { 15.4:1.1 }\end{array}$ & - & - & 17 & Bai (2015) \\
\hline- & - & - & $\begin{array}{l}\text { GlcA: Rha: Xyl: Fru: Glc=1.10:6.38:2.30: } \\
\text { 2.83:12.34 }\end{array}$ & - & - & - & $\begin{array}{l}\text { Zhang and } \\
\text { Sun, (2015) }\end{array}$ \\
\hline- & - & - & $\begin{array}{l}\text { Ara: Glu: Gal: Xyl: GalA }=51.4: 24.5: 10.2: \\
5.7: 4.9\end{array}$ & - & - & $74,38,45,23$ & $\begin{array}{l}\text { Wang et al. } \\
(2016)\end{array}$ \\
\hline- & - & - & Ara: Xyl: Gluc: Man=7.1:22.3:7.6:1.0 & - & - & - & Meng (2018) \\
\hline 12 & ASPA & Root & $\begin{array}{l}\text { Man: Rha: GlcA: GalA: Glc: Gal: Xyl: Ara: } \\
\text { Fuc= 0.3:13.5:1.9:27:3.6:22.3:15.1: } \\
15.7: 0.6\end{array}$ & $R G-1, A G-\|, X G A$ & - & - & Bai (2015) \\
\hline 13 & ASPN & Root & $\begin{array}{l}\text { Man: Rha: GlcA: GalA: Glc: Gal: Xyl: Ara: } \\
\text { Fuc =4.3:4.5:1:1.7:25.7:32.9:7.1:22.6:0.2 }\end{array}$ & - & - & - & Bai (2015) \\
\hline 14 & ASPA-1 & Root & $\begin{array}{l}\text { Man: Rha: GlcA: GalA: Glc: Gal: Xyl: Ara = } \\
\text { 0.2:13:0.8:35.9:0.6:17:25.3:7.2 }\end{array}$ & $R G-1, X G A$ & - & - & Bai (2015) \\
\hline- & ASPA-2 & Root & $\begin{array}{l}\text { Man: Rha: GlcA: GalA: Glc: Gal: Ara = 0.4: } \\
\text { 11.4:1.8:15.7:2.2:44.7:23.8 }\end{array}$ & $\mathrm{RG}-1$ & - & 400 & Bai (2015) \\
\hline 15 & ASPA-1-A & Root & $\begin{array}{l}\text { Man: Rha: GlcA: GalA: Glc: Gal: Xyl: Ara: } \\
\text { Fuc=0.4:14.8:1.1:26.9:0.6:20.4:27.1: } \\
\text { 8.3:0.4 }\end{array}$ & $R G-1, X G A$ & - & $48,40,37$ & Bai (2015) \\
\hline- & ASPA-1-B & Root & $\begin{array}{l}\text { Man: Rha: GlcA: GalA: Glc: Gal: Xyl: Ara: } \\
\text { Fuc=0.4:11.7:0.9:46.2:1:14.1:20.4: } \\
5.1: 0.2\end{array}$ & $R G-1, X G A$ & - & 11,10 & Bai (2015) \\
\hline 16 & ABPS-21 & Stem & $\begin{array}{l}\text { Gal: Glc: Rha: GalA =3.0:2.0:2.0:1.0 } \rightarrow 4)- \\
\text { D-Galp-(1 } \rightarrow 4)-D-G l c p-(1 \rightarrow 4)-D-\end{array}$ & $\begin{array}{c}\alpha-L-\text { Rhap- }(1 \rightarrow 4)-\beta-D- \\
\text { Glcp- }(1 \rightarrow\end{array}$ & 106 & - & Hu et al. (2015) \\
\hline- & - & - & - & $\begin{array}{l}\text { Galp- }(1 \rightarrow 4)-D-G a l p- \\
(1 \rightarrow 2)-\alpha-L-R h a p-(1 \rightarrow\end{array}$ & $\begin{array}{l}\alpha-D-G a l p A-(1 \rightarrow O-6 \\
1,4,6 \text {-linked } \beta \text {-D-Glcp }\end{array}$ & - & - \\
\hline- & - & - & - & - & $\begin{array}{c}\alpha-L-\text { Rhap- }(1 \rightarrow 4)-\beta-D- \\
\text { Glcp- }(1 \rightarrow\end{array}$ & - & - \\
\hline
\end{tabular}


TABLE 2 | (Continued) Structural characterization of polysaccharides isolated from the different parts of Eleutherococcus senticosus.

\begin{tabular}{|c|c|c|c|c|c|c|c|}
\hline No & $\begin{array}{l}\text { Compound } \\
\text { Name }\end{array}$ & $\begin{array}{l}\text { Medical } \\
\text { Parts }\end{array}$ & Monosaccharide Composition $^{a}$ & $\begin{array}{c}\text { Main chain } \\
\text { composition/ } \\
\text { structural domain }\end{array}$ & Branch composition & M.W. (KDa) & Reference \\
\hline- & - & - & - & - & $\begin{array}{c}\alpha \text {-D-GalpA- }(1 \rightarrow \text { O-6 } \\
1,4,6 \text {-linked } \beta \text {-D-Galp }\end{array}$ & - & - \\
\hline- & ABPS-21P & Stem & Gal: Glc: Rha =3.0:1 $\cdot 0: 1 \cdot 0$ & - & - & 8.25 & Hu et al. (2015) \\
\hline 17 & ANP & Buds & Ara: Man: Glc: Gal=1.0:2.6:2.5:1.4 & - & - & 10.7 & $\begin{array}{l}\text { Lee et al. } \\
(2015)\end{array}$ \\
\hline- & AAP & Buds & Ara: Gal: 4-O-methyl-D-GlcA = 5:10:1 & AG-II & - & 84 & $\begin{array}{l}\text { Lee et al. } \\
(2015)\end{array}$ \\
\hline 18 & CASPS & Root & Ara: Man: Rha: Gal: Glc =1:1.1:3:4.7:5 & - & - & $70,38,120,19$ & Xie et al. (2015) \\
\hline
\end{tabular}

${ }^{a}$ Ara, arabinose; Fuc, fucose; Fru, fructose; Gal, galactose; Glc, glucose; GalA, galacturonic acid; GlcA, glucuronic acid; Man, mannose; Rha, rhamnose; Rib, ribose; Xyl, xylose; AG, arabinogalactans; $R G$, rhamnogalacturonan; XGA, xylogalacturonan.

phenol-sulfuric acid method was more convenient. Using phenolsulfuric acid method, the content of ESPS after freeze-drying was $51.9-56.5 \%$, while that obtained by spray-drying was $50.5-53.1 \%$ (Zhang and Sun, 2005).

Existing data from literatures reveal that the variation explained by the content of ESPS ranged from 1.52 to $13.21 \%$ due to the limitation of the extracted part and process of $E$. senticosus. How to further increase the content of ESPS is still the direction we need to work hard on.

\section{Structural Characterization of Polysaccharides}

The polysaccharide belongs to a kind of high molecular polymer with a relative molecular weight $(\mathrm{Mw})$ ranging from tens of thousands to tens of millions connected by glycosidic bonds. The structure identification of polysaccharides could be accomplished by the determination of the purity, monosaccharide composition, $\mathrm{Mw}$, position and sequence of carbohydrate connection, glycoside bond configuration and oxygen ring. Several technologies including acid hydrolysis, methylation, periodic acid oxidation, Smith degradation, alkaline degradation, enzymatic hydrolysis, biological analysis, physical analysis (including IR, MS, ESI-MS, MALDI-MS, NMR, CE, GC, etc.)) would be employed.

The early research on structure of ESPS was limited to incomplete and inaccurate characterization by equipment and technology. Mw and monosaccharide composition were the only detected items for ESPS. The Mw of polysaccharides was obtained by measuring the standard dextran with known Mw. Based on this approach, PES-A and PES-B with 7 and $76 \mathrm{kDa}$ together with immunologically active polysaccharides As-II and As-II with 150 and $30 \mathrm{kDa}$ were purified from the root of E. senticosus (Xu, 1983). In the 21st century, the structure research and chemical modification technology of ESPS become more mature, high performance gel permeation chromatography (HPGPC) analysis technology with more accurate and fast superiority is developed to determine the $\mathrm{Mw}$ distribution and uniformity of polysaccharides based on the molecular sieve principle. Accordingly, several ESPS with $\mathrm{Mw}$ ranging from 7 to $400 \mathrm{kDa}$ were reported (Wang, 2006). Their structural information is provided in Table 2. It is worth noting that the separation range of the HPGPC column possess the significant influence on the determination results. Bai et al. compared the Mw of the same ESPS samples separated by two specifications of columns from TSK-gel company. Results showed that Mw of ESPS-1-A and ASPA-1-B were 48 and $11 \mathrm{kDa}$ by G-3000PWXL, while the value were 37 and $10 \mathrm{kDa}$ by G-4000PWXL, respectively (Bai, 2015). As ASPS-1-A possessed larger Mw, more significant influence on it was present. This reminds us that the choice of chromatographic column is very important.

The determination of monosaccharide composition of polysaccharides has been improved and perfected. In the initial stages, thin layer chromatography (TLC) method was used by comparing the specific $\mathrm{Rf}$ value with each monosaccharide standard. While TLC can only provide the type of monosaccharides like ASC-2 and ASH-1P3 (Wang, 2006), their proportion could not be given as TLC is an unquantifiable method. Instead, gas chromatography (GC) could realize the measurement of above two respects based on the derivatization method. After GC analysis, the proportion of monosaccharides of PES-A (Xu, 1983), ASA-1P3A and ASA-1P3B had been supplied, which also provides key information for the subsequent estimate of ESPS types. Besides, the results in Table 2 showed that GalA and Gal possessed relatively high proportion in ESPS.

In recent years, more in-depth research into chain sequencing and structural domain of carbohydrate is developed based on the requirement of pharmacology, toxicology and structural modification. According to the sequence, mode, and monosaccharide types of glycosylation in the main chain, the structure of ESPS could be divided into three types, namely RG-I, XGA and AG-II. 1) RG-I: Most of ESPS belong to the polysaccharides with RG-I structure due to high content of Rha and GalA connected through $1 \rightarrow 4$ linkage. Besides, the Rha/GalA ratios in different samples ranged from 0.25 to 0.73 indicated that they may be inducted as pectin. 2) XGA: XGA domain represent for some polysaccharides with higher $\mathrm{Xyl}$ content. Accordingly, the $\mathrm{Xyl} / \mathrm{GalA}$ ratios 1.0 and 0.44 obtained from ASPA-1-A and ASPS-1-B suggest that XGA domain existed in both components. Moreover, several XGA domains also coexist with RG-I domain in other ESPS samples (Bai, 2015). 3) AG-II: Three kinds of ESPS named ASPA (Bai, 2015), ANP (Lee et al., 2015), and AAP (Lee et al., 2015)were found as AG-II pectin due to major connection of Ara and Gal through $1 \rightarrow 3$ linkage. However, the structure of ESPS was irregularly in branch composition. 


\section{BIOLOGICAL ACTIVITIES}

\section{Anti-tumor Activity \\ Anti-lung Cancer Activity}

Lung cancer remains the leading cause of cancer deaths all over the word. It is generally divided into non-small cell lung cancer (NSCLC) and small cell lung cancer (SCLC), respectively. However, SCLC was harder to cure due to its high invasiveness, low tumor differentiation, high deterioration as well as poor results of chemotherapy and surgery. Some studies had confirmed that ESPS could inhibit the proliferation of human SCLC cell line H446 using MTT, FCM and Hoechst33258 staining methods (Zhao, 2008a), and promote the apoptosis of $\mathrm{H} 446$ cells by up-regulating the expression of Bax and p53 genes and down-regulating the expression of $\mathrm{Bcl}-2$ genes (Zhao, 2008b), and lead to G2/M phase arrest to interfere with H446 cell cycle progression by activating the ERK1/2 pathway (Zhao, 2010). Besides, the intervention effect of ESPS on the incidence of Lewis LC was also observed. In vivo, inhibition of tumor growth by ESPS was also manifested by decreasing the levels of PAI-1 and $\mu \mathrm{PA}$ in plasma, tumor and lung tissue. Moreover, combined administration of cyclophosphamide (CTX) and ESPS exhibited better effect than a single group of drugs (Zhang, 2001). Similarly, Sun et al. explored transwell and wound healing assay to evaluate the anti-tumor activity of ESPS on NCI-H520 cells after 24 and $48 \mathrm{~h}$, decreased proliferation as well as repressed invasion and migration associated with Wnt/ $\beta$-catenin pathway mediated-EMT provided new theoretical knowledge for NSCLC (Sun et al., 2019). In addition, Aidi injection is a proprietary Chinese medicine extracted from $E$. senticosus to treat stage IIIB/IV non-small cell lung cancer, and this therapeutic effect seems to be related to ESPS (Wang et al., 2018).

\section{Anti-liver Cancer Activity}

In recent years, some studies have found that ESPS also showed remarkable biological activity against liver cancer. In 1997, Zhang et al. found that ESPS had a significant inhibitory effect on hepatocellular carcinoma induced by chemical carcinogens (3'me-DAB) (Zhang et al., 1997). In vitro experiments showed that ESPS could induce apoptosis and G0/G1 phase cell cycle growth arrest in HepG2 cells by targeting Wnt/ $\beta$-catenin pathway (Wang et al., 2016). Anti-hepatic carcinoma assay experiment of ASC-1 and ESPS on mouse $\mathrm{H} 22$ transplanted tumors also showed a preventive effect. Compared with the white water group, the tumor suppression rate of ASC-1 reached 39.13\% (Wang, 2006), and the tumor quality of the ESPS group was significantly lower than that of the control group (Meng, 2018). It can be inferred that ESPS indirectly suppressed hepatic carcinoma by enhancing the immunity of the body.

\section{Other Anti-cancer Activity}

Malignant tumors remain a serious disease that threatens human health. Currently, previously discovered ESPS have shown effects on cervical cancer, sarcoma, and laryngeal cancer of varying degrees along with the advantages of safety, efficacy and low toxicity. It can be used as antineoplastic and anti-tumor adjuvant drugs. As early as 1993, Cao et al. found that intragastric administration of ESPS at $10 \mathrm{mg} / \mathrm{kg}$ promoted the proliferation of mouse spleen cells and enhanced the activity of LAK cells, which provides an ideal biological response adjustment for LAK/ IL-2 tumor cell therapy agents (Cao and Du, 1993). Meng et al. founded that different doses of ESPS $(200,100$ and $50 \mathrm{mg} / \mathrm{kg})$ could significantly inhibit the growth of sarcoma S180 and cervical cancer U14 on tumor-bearing mice and prolonged their survival time. Among which, $100 \mathrm{mg} / \mathrm{ml}$ dose possessed the best activity (Meng, 2018). Simultaneously, Tong et al. confirmed that ESPS has a direct anti-tumor effect on sarcoma S180 cells, whose inhibition rate exceeds $70 \%$ and half effective inhibitory concentration is $0.38 \mathrm{~g} / \mathrm{L}$ (Tong, 1994). Besides, studies have also shown that ESPS can inhibit the proliferation of human cervical cancer HeLa cells via promoting the expression of Bax protein. At the same time, it may down-regulate the expression of survivin protein (Jin, 2014; Jin, 2016), thereby promoting the apoptosis of HeLa cells. ESPS inhibited the proliferation of CD133-positive stem cells in laryngeal cancer Hep-2, which may be related to the influence of ESPS on the expression levels of PD-L1 and Bcl-2 to promote stem cell apoptosis (Chen et al., 2019). This important discovery lays the foundation for the targeted therapy of laryngeal cancer stem cells.

\section{Immunoregulatory Activity}

Immunomodulation is considered to be one of the important physiological functions for the body to identify and remove antigenic foreign bodies as well as maintain physiological dynamic balance and relative stability. Abnormalities in the immune system could cause a variety of diseases such as infection, inflammation and cancer (Yu et al., 2018). In recent years, ESPS has been proved to have a certain regulatory effect on the immune system of mice. On the one hand, it can directly activate the immune function of $\mathrm{T}, \mathrm{B}$ lymphocytes and macrophages by regulating immune organs; on the other hand, it can also play its biological activity by regulating the level of cytokines. Many studies have shown that intraperitoneal injection or intragastric administration of ESPS could increase the weight of thymus and spleen and improve immune function in mice (Chen, 1984; Xie, 1989a; Xu, 1990). Moreover, this regulatory effect may be positively correlated with the dose. Sun et al. found that the immune organ index, peripheral blood leukocyte count and macrophage phagocytosis of CTX-induced immunocompromised mice were increased by intragastric administration of different doses of ESPS aqueous solution $(6 \mathrm{mg} / 10 \mathrm{~g}, 12 \mathrm{mg} / 10 \mathrm{~g}$ and $24 \mathrm{mg} / 10 \mathrm{~g})$, and the efficacy of high dose group was significantly (Sun et al., 2018). Equally, Luo et al. also found that high-dose ESPS could significantly promote the proliferation of spleen lymphocytes and increase the ratio of $\mathrm{CD}^{+} \mathrm{CD}^{+} / \mathrm{CD}^{+} \mathrm{CD}^{+}$(Luo, 2013a). In addition, ESPS can also improve the innate immune function of the body by reducing the levels of cytokines such as IFN- $\gamma$, IL-2, IL- 6 and TNF- $\alpha$ (Diao, 2008a; Han et al., 2014; Zhang, 2015). In vitro, ESPS could significantly promote lymphocyte proliferation induced by concavalinA and LPS, and this effect is not related to endotoxin (Chen et al., 2011). These studies provide abundant evidence for ESPS as a natural immunostimulant agent. However, the present research on the immune activity of ESPS remains on the animal 
level, and whether it can be used in clinic needs more in-depth research.

\section{Antioxidant Activity}

As we all know, the production of free radicals has the beneficial effects of regulating cell growth and inhibiting viruses and bacteria (Diao, 2008c). Nevertheless, excessive free radicals will lead to excessive reactive oxygen species (ROS) formation and break the redox homeostasis. This is closely related to some human chronic diseases, such as cancer, arteriosclerosis and aging (Diao et al., 2010b). ESPS have been proved to have significant scavenging effects on a variety of free radicals, such as hydroxyl radicals, superoxide anions and hydrogen peroxide. In vitro, Chen and Zhao reported that ESPS had obvious scavenging activity evaluated by ferric reducing antioxidant power assay (FRAP), Fenton's reaction, pyrogallol's auto oxidation and $\mathrm{DPPH}$ radical scavenging experiments in a concentrationdependent manner (Jiao, 2008) (Meng et al., 2005; Diao, 2008d; Chen, 2011b). Xia et al. compared the antioxidant capacity of two water-soluble polysaccharides (ASP-B2 and ASP-B3) extracted from the leaves of E. senticosus. It is worth noting that the clearance rates of ASP-B2 and ASP-B3 for DPPH reached $91.75 \pm 0.59 \%$ and $91.58 \pm 1.58 \%$ at $2.0 \mathrm{mg} / \mathrm{ml}$, respectively (Diao, 2008b). Likewise, ESPS extracted from fruits also showed antioxidant activity. Among the concentration range from 0.05 to $0.8 \mathrm{mg} / \mathrm{ml}$, the scavenging rates of ESPS to DPPH and ABTS increased in a concentration-dependent manner, and the highest scavenging rates were $65.21 \pm 1.85 \%$ and $58.02 \pm 1.25 \%$, respectively (Diao, 2009b).

Meantime, researchers also focused on the antioxidant activity of ESPS in vivo. It is reported that the activities of superoxide dismutase (SOD) and GSH-Px increased in a dose-dependent manner after 15 days of intragastric administration of ESPS (50, 100 and $200 \mathrm{mg} / \mathrm{kg} / \mathrm{d}$ ) in rats with cerebral ischemia-reperfusion. As SOD is the most important antioxidant enzyme for scavenging free radicals in vivo, the result suggests that ESPS may improve cerebral ischemia-reperfusion injury by improving the antioxidant capacity of brain tissue (Xie et al., 2015). Similarly, Long et al. found that ESPS could also improve the growth performance of chicks by increasing the activities of SOD and GSH-Px (Long et al., 2021). Besides that, some domestic scholars have also found that ESPS can significantly protect rat hippocampal neurons from oxidative stress damage induced by $\mathrm{H}_{2} \mathrm{O}_{2}$ (Diao et al., 2010b; Liu et al., 2013). Above studies indicated that ESPS seem to be used as a potential natural antioxidant. However, there is a big gap between the clinical application and fundamental research, which need further explore in the future.

\section{Anti-inflammatory Activity}

Inflammation is a response to pathogens and tissue damage. This process is mainly caused by a series of pathological reactions of the injured site by stimulating immune cells to release inflammatory mediators. However, long-term inflammation is the main cause of aging and serious diseases, such as inflammatory bowel disease, cardiovascular disease (CVD), hepatitis and cancer (Diao, 2009d). In the past decades, the natural polysaccharides extracted from $E$. senticosus showed significant anti-inflammatory activity. Many studies have shown that ESPS could regulate the level of inflammatory mediators in vivo and reduce the infiltration of inflammatory cells in multiple organs. It is reported that ESPS pretreatment reduced the secretion and expression of inflammatory cytokines such as IL-2, IL-4 and INF- $\gamma$, which has a certain protective effect on immune liver injury (Zhu et al., 1982; Xie, 1989c; Luo, 2013b; Han, 2013; Zhang, 2018; Zhai, 2020). Similarly, ESPS could also inhibit the activation of NF- $\kappa \beta$ in mouse liver tissue and endotoxic shock induced by LPS/D-GalN (Diao, 2009c). Xie et al. also reported that intragastric administration of ESPS could reduce the contents of IL- $1 \beta$ and TNF- $\alpha$ in brain tissue and exhibit a certain protective effect on cerebral ischemia-reperfusion injury (Zhang et al., 2019). In addition, Han and Fan et al. have verified that ESPS could improve a variety of inflammatory bowel diseases induced by LPS, whose effect is mainly mediated by NF- $\kappa \mathrm{B} / \mathrm{MLCK}$, HIF-1 $\alpha / \mathrm{COX}-2$ and TLR4/ NF- $\kappa B$ signal pathways (Yang et al., 1983; Yang et al., 1985; Poolsup et al., 2004; Luo, 2008; Mo, 2012a; Mo, 2012b; Han et al., 2016a; Han et al., 2016b; Lu, 2016; Yang, 2016; Han et al., 2017; Pan, 2019b; Zhang et al., 2020a). Clinically, Poolsup et al. conducted a statistical analysis of 433 patients with upper respiratory tract infection and found that E. senticosus was more effective than placebo. Whether this effect is related to ESPS needs to be further explored (Poolsup et al., 2004).

\section{Other Biological Activities}

Apart from to above biological activities, ESPS also possess the activities of analgesia, anti-radiation, anti-fatigue as well as compatibility with other drugs to treat diabetes and leukemia. As early as the end of the 20th century, ESPS was reported to increase the ability to produce IFNs in S801 and S7811 leukemia cell lines (Diao, 2008b; Diao, 2008c; Diao, 2008d; Diao, 2009a; Diao, 2009b). Similarly, the proliferation of leukemia cells K562 and Pmur388 original from human and mice were also inhibited by ESPS (Diao, 2009c; Jin, 2016). Moreover, Mo et al. reported that ESPS also had anti-radiation effect (Diao et al., 2010a; Diao et al., 2010b). ESPS has also shown a protective effect on the gastrointestinal tract, reproductive system, and peripheral blood cells of rats irradiated by 60Co gamma rays (Diao et al., 2010c). It's worth noting that magical effect of ESPS as an adjuvant therapy for diabetes was discovered by the rapidly reduced blood glucose after combined use of ESPS with Metformin, whose efficacy on the level of blood lipids (TC and TG), thiobarbituric acid reactive substances (TBARS), AST, ALT, ALP, total bilirubin, creatinine and urea was better than that of Metformin (Fu et al., 2012).

Besides, ESPS can also improve exercise-induced energy metabolism, increase serum creatinine level and reduce protein decomposition, which exhibits a significant anti-fatigue potential (Han, 2007; Bang et al., 2015). Others used metabonomics methods to investigate the mechanism of ESPS on Alzheimer's disease and CVD rats by detecting the endogenous substances, 20 potential biomarkers such as 6-dimethylaminopurine and L-acetylcarnitine were screened out ( $\mathrm{Lu}, 2015)$. Table 3 and 
TABLE 3 | Pharmacological activities and involved mechanism of ESPS.

\begin{tabular}{|c|c|c|c|c|c|c|c|c|c|c|c|}
\hline $\begin{array}{l}\text { Biological } \\
\text { activity }\end{array}$ & $\begin{array}{l}\text { Compound } \\
\text { Name }\end{array}$ & $\begin{array}{l}\text { Medical } \\
\text { Parts }\end{array}$ & Model & $\begin{array}{l}\text { Vivo/ } \\
\text { Vitro }\end{array}$ & $\begin{array}{l}\text { Administration } \\
\text { Route }^{\mathrm{a}}\end{array}$ & Dose & Duration & $\begin{array}{l}\text { Cytokine/ } \\
\text { Enzyme } \\
\text { /Protein }\end{array}$ & Results & $\begin{array}{c}\text { Involved } \\
\text { Mechanism }\end{array}$ & References \\
\hline \multirow[t]{8}{*}{$\begin{array}{l}\text { Anti-lung } \\
\text { cancer }\end{array}$} & ESPS & Root & $\begin{array}{l}\text { Female C57/ } \\
\text { BLmice }\end{array}$ & $\begin{array}{l}\text { In } \\
\text { vivo }\end{array}$ & i.p. & $0.12 \mathrm{ml} / \mathrm{piece}$ & - & $\mu \mathrm{PA} \downarrow$ & Intervene of lung cancer & PAl-1 $\downarrow$ & $\begin{array}{l}\text { Zhang } \\
\text { (2001) }\end{array}$ \\
\hline & ESPS & Root & H446 cells & $\begin{array}{l}\text { In } \\
\text { vitro }\end{array}$ & - & $240,480,960 \mu \mathrm{gg} / \mathrm{ml}$ & $48 \mathrm{~h}$ & - & Cell proliferation $\downarrow$ & $\begin{array}{l}\text { P53, Bax } \uparrow, \mathrm{Bcl}-2 \\
\text { expression } \downarrow \text { Apoptosis }\end{array}$ & Zhao (2018) \\
\hline & ESPS & Root & H446 cells & $\begin{array}{l}\text { In } \\
\text { vitro }\end{array}$ & - & $240,480,960 \mu \mathrm{g} / \mathrm{ml}$ & $48 \mathrm{~h}$ & TNF- $a$, IL-1 & Cell proliferation $\downarrow$ & $\begin{array}{l}\text { P53,Bax } \uparrow, B c 1-2 \downarrow p-38 \\
\text { expression EPK } \\
\text { pathway, Apoptosis }\end{array}$ & Zhao (2018) \\
\hline & ESPS & Root & H446 cells & $\begin{array}{l}\text { In } \\
\text { vitro }\end{array}$ & - & $240,480,960 \mathrm{mg} / \mathrm{l}$ & $48 \mathrm{~h}$ & - & G2/M arrest $\downarrow$ & $\begin{array}{l}\text { EPK MAP kinase } \\
\text { pathways }\end{array}$ & Zhao (2010) \\
\hline & ESPS & Root & $\begin{array}{l}\text { NSCLC NCl- } \\
\mathrm{H} 520\end{array}$ & $\begin{array}{l}\text { In } \\
\text { vitro }\end{array}$ & - & $\begin{array}{l}\text { 10,20,40,80,160, } \\
320 \mathrm{mg} / \mathrm{ml}\end{array}$ & $12,24,48 \mathrm{~h}$ & $\begin{array}{l}\text { MMP2, MMP9, } \\
\text { FN1, wnt3a }\end{array}$ & $\begin{array}{l}\text { Proliferation, } \\
\text { metastasis } \downarrow\end{array}$ & $\begin{array}{l}\text { Wnt/ } \beta \text {-catenin } \\
\text { pathways }\end{array}$ & $\begin{array}{l}\text { Sun et al. } \\
\text { (2019) }\end{array}$ \\
\hline & ASC-1 & Root & A-549 cells & $\begin{array}{l}\text { In } \\
\text { vitro }\end{array}$ & - & ASC-1 $35.7 \mu \mathrm{M}$ & 11 days & - & Cell viability $\downarrow$ & - & $\begin{array}{l}\text { Wang, } \\
(2006)\end{array}$ \\
\hline & ASA-1 & Root & - & - & - & ASA-1 $125 \mu \mathrm{M}$ & - & - & - & - & - \\
\hline & $\mathrm{ASH}-1$ & Root & - & - & - & ASH-1 $163.5 \mu \mathrm{M}$ & - & - & - & - & - \\
\hline \multirow[t]{8}{*}{$\begin{array}{l}\text { Anti-liver } \\
\text { cancer }\end{array}$} & ESPS & Root & $\begin{array}{l}\text { Mice, HEPA } \\
\text { cells }\end{array}$ & $\begin{array}{l}\text { In } \\
\text { vivo }\end{array}$ & s.c. & $0.34 \mathrm{~g} / \mathrm{kg} / \mathrm{d}$ & 10 days & - & The life of mice $\uparrow$ & - & Chen (1984) \\
\hline & ASC-1 & Root & $\begin{array}{l}\text { Male Kunming } \\
\text { mice, }\end{array}$ & $\begin{array}{l}\text { In } \\
\text { vivo }\end{array}$ & i.g. & 2 mg/piece & 11 days & $\begin{array}{l}\text { ASC-1 prevent } \\
\text { seed tumors }\end{array}$ & - & - & $\begin{array}{l}\text { Wang, } \\
(2006)\end{array}$ \\
\hline & ASA-1 & Root & - & $\begin{array}{l}\mathrm{H} 22 \\
\text { cells }\end{array}$ & i.p. & 0.04 mg/piece & - & - & $\begin{array}{l}\text { ASA-1no anti-tumor } \\
\text { effect }\end{array}$ & - & - \\
\hline & ESPS & Root & $\begin{array}{l}\text { Kunming } \\
\text { mice, }\end{array}$ & $\begin{array}{l}\text { In } \\
\text { vivo }\end{array}$ & i.g. & $50,100,200 \mathrm{mg} / \mathrm{kg} / \mathrm{d}$ & 10 days & TNF- $\alpha$, TNF- $\gamma$ & $\begin{array}{l}\text { Survival days } \uparrow \text {,regulate } \\
\text { cytokines }\end{array}$ & - & $\begin{array}{l}\text { Meng, } \\
(2018)\end{array}$ \\
\hline & - & - & H22cells & - & - & - & - & IL-2, IL-12 & - & - & - \\
\hline & PAS & Root & C57BL/6 mice & $\begin{array}{l}\text { In } \\
\text { vivo }\end{array}$ & i.p. & $10 \mathrm{mg} / \mathrm{kg} / \mathrm{d}$ & 14 days & IL-2R, LAK & $\begin{array}{l}\text { LAK activity } \uparrow \text {, } \\
\text { splenocyte } \uparrow\end{array}$ & - & $\begin{array}{l}\text { Cao and Du, } \\
\text { (1993) }\end{array}$ \\
\hline & ESPS & Root & $\begin{array}{l}\text { Male } \\
\text { Wister rat }\end{array}$ & $\begin{array}{l}\text { In } \\
\text { vivo }\end{array}$ & i.g. & $20 \%$ & 70 days & $\gamma$-GT $\uparrow$ & Inhibit tumor & - & $\begin{array}{l}\text { Zhang et al. } \\
\text { (1997) }\end{array}$ \\
\hline & ESPS & Root & HepG2 cells & $\begin{array}{l}\text { In } \\
\text { vitro }\end{array}$ & - & $0,10,20,40,80 \mathrm{mg} / \mathrm{L}$ & $48 \mathrm{~h}$ & - & $\begin{array}{l}\text { Apoptosis } \uparrow, \text { Go/G1 } \\
\text { phase arrest in }\end{array}$ & Wnt/ß-catenin pathway & $\begin{array}{l}\text { Wang et al. } \\
(2016)\end{array}$ \\
\hline \multirow[t]{9}{*}{$\begin{array}{l}\text { Anti-other } \\
\text { tumors }\end{array}$} & ESPS & Root & $\begin{array}{l}\text { Kunming } \\
\text { mice, }\end{array}$ & $\begin{array}{l}\text { In } \\
\text { vivo }\end{array}$ & i.g. & $50,100,200 \mathrm{mg} / \mathrm{kg} / \mathrm{d}$ & 10 days & $\mathrm{IL}-2, \mathrm{IL}-12, \mathrm{INF}-\gamma$ & Cell growth $\downarrow$ & Apoptosis & $\begin{array}{l}\text { Meng et al. } \\
(2018)\end{array}$ \\
\hline & ESPS & Root & $\begin{array}{l}\text { Kunming } \\
\text { mice, }\end{array}$ & $\begin{array}{l}\text { In } \\
\text { vivo }\end{array}$ & i.g. & $50,100,200 \mathrm{mg} / \mathrm{kg} / \mathrm{d}$ & 10 days & TNF- $\alpha$, TNF- $\gamma$, & $\begin{array}{l}\text { Survival days } \uparrow \text {, regulate } \\
\text { cytokines }\end{array}$ & Immunomodulation & $\begin{array}{l}\text { Meng, } \\
(2018)\end{array}$ \\
\hline & - & - & U14 cells & - & - & - & - & $\mathrm{IL}-2, \mathrm{IL}-12$ & - & - & - \\
\hline & ESPS & Root & Hela cells & $\begin{array}{l}\text { In } \\
\text { vitro }\end{array}$ & - & $1,2,4,8,16 \mathrm{mg} / \mathrm{ml}$ & $24,48,72 \mathrm{~h}$ & - & Cell proliferation $\downarrow$ & $\begin{array}{l}\text { Bax expression } \uparrow, \\
\text { Apoptosis }\end{array}$ & Jin (2014) \\
\hline & ESPS & Root & Hela cells & $\begin{array}{l}\text { In } \\
\text { vitro }\end{array}$ & - & $1,2,4,8,16 \mathrm{mg} / \mathrm{ml}$ & $24,48,72 \mathrm{~h}$ & - & Cell proliferation $\downarrow$ & $\begin{array}{l}\text { Survivin expression } \downarrow \text {, } \\
\text { Apoptosis }\end{array}$ & Jin (2016) \\
\hline & ESPS & Root & $\begin{array}{l}\text { Kunming } \\
\text { mice, }\end{array}$ & $\begin{array}{l}\text { In } \\
\text { vivo }\end{array}$ & i.g. & $50,100,200 \mathrm{mg} / \mathrm{kg} / \mathrm{d}$ & 10 days & TNF- $\alpha$, TNF- $\gamma$, & $\begin{array}{l}\text { Survival days } \uparrow \text {, regulate } \\
\text { cytokines }\end{array}$ & Immunomodulation & $\begin{array}{l}\text { Meng, } \\
(2018)\end{array}$ \\
\hline & - & - & S180cells & - & - & - & - & $\mathrm{IL}-2, \| \mathrm{L}-12$ & - & - & - \\
\hline & ESPS & Root & $\begin{array}{l}\text { Mice } \\
\text { S37,S180 } \\
\text { cells }\end{array}$ & $\begin{array}{l}\text { In } \\
\text { vivo }\end{array}$ & S.C & $0.34 \mathrm{~g} / \mathrm{kg} / \mathrm{d}$ & 10 days & - & $\begin{array}{l}\text { Excited } \\
\text { reticuloendothelial } \\
\text { system }\end{array}$ & Immunomodulation & Chen (1984) \\
\hline & ESPS & Root & S180cells & $\begin{array}{l}\text { In } \\
\text { vitro }\end{array}$ & - & 1,10,100,500, & $24 \mathrm{~h}$ & - & Cell proliferation $\downarrow$ & Apoptosis & Tong (1994) \\
\hline
\end{tabular}


TABLE 3 | (Continued) Pharmacological activities and involved mechanism of ESPS.

\begin{tabular}{|c|c|c|c|c|c|c|c|c|}
\hline $\begin{array}{l}\text { Biological } \\
\text { activity }\end{array}$ & $\begin{array}{l}\text { Compound } \\
\text { Name }\end{array}$ & $\begin{array}{l}\text { Medical } \\
\text { Parts }\end{array}$ & Model & $\begin{array}{l}\text { Vivo/ } \\
\text { Vitro }\end{array}$ & $\begin{array}{l}\text { Administration } \\
\text { Route }^{\mathrm{a}}\end{array}$ & Dose & Duration & $\begin{array}{l}\text { Cytokine } \\
\text { Enzyme } \\
\text { /Protein }\end{array}$ \\
\hline & - & - & - & - & - & $1000 \mathrm{mg} / \mathrm{l}$ & - & - \\
\hline & ESPS & Root & Hep 2 CD133 & $\begin{array}{l}\text { In } \\
\text { vitro }\end{array}$ & - & 100 mg/l & $24,48,72 \mathrm{~h}$ & $\mathrm{BCl}-2, \mathrm{PD}-\mathrm{L} 1$ \\
\hline \multirow[t]{12}{*}{$\begin{array}{l}\text { Immuno- } \\
\text { modulatory }\end{array}$} & PES-W & Root & $\begin{array}{l}\text { Female } \\
\text { C57BL mice }\end{array}$ & $\begin{array}{l}\text { In } \\
\text { vivo }\end{array}$ & i.p. & $100 \mathrm{mg} / \mathrm{kg} / \mathrm{d}$ & 5 days & - \\
\hline & PES-A & - & - & - & - & - & - & $\begin{array}{l}\text { spleen and } \\
\text { thymus } \uparrow\end{array}$ \\
\hline & PES-B & - & - & - & - & - & - & - \\
\hline & PES-W & Root & $\begin{array}{l}\text { Female } \\
\text { C58BL mice }\end{array}$ & $\begin{array}{l}\text { In } \\
\text { vivo }\end{array}$ & i.p. & $100 \mathrm{mg} / \mathrm{kg} / \mathrm{d}$ & 4 days & - \\
\hline & PES-A & - & - & - & - & - & - & - \\
\hline & PES-B & - & - & - & - & - & - & - \\
\hline & ESPS & Root & Mice & $\begin{array}{l}\text { In } \\
\text { vivo }\end{array}$ & i.p. & $30 \mathrm{mg} / \mathrm{kg} / \mathrm{d}$ & 3 days & - \\
\hline & ESPS & Root & Mice & $\begin{array}{l}\text { In } \\
\text { vivo }\end{array}$ & i.p. & $30 \mathrm{mg} / \mathrm{kg} / \mathrm{d}$ & 3 days & - \\
\hline & ESPS & Root & Mice & $\begin{array}{l}\text { In } \\
\text { vivo }\end{array}$ & s.c. & $0.067 \mathrm{~g} / \mathrm{kg} / \mathrm{d}$ & 3 days & - \\
\hline & ASII & Root & Mice & $\begin{array}{l}\text { In } \\
\text { vivo }\end{array}$ & - & - & - & - \\
\hline & ASIII & - & - & - & - & - & - & - \\
\hline & ESPS & Root & $\begin{array}{l}\text { Male BALB/c, } \\
\text { C57BL/6 mice }\end{array}$ & $\begin{array}{l}\text { In } \\
\text { vivo }\end{array}$ & i.p. & $100 \mathrm{mg} / \mathrm{kg} / \mathrm{d}$ & 10 days & ConA, LPS \\
\hline \multirow[t]{12}{*}{$\begin{array}{l}\text { Immuno- } \\
\text { Modulatory }\end{array}$} & ESPS & Root & $\begin{array}{l}\text { Male BALB/c, } \\
\text { C57BL/7 mice }\end{array}$ & $\begin{array}{l}\text { In } \\
\text { vivo }\end{array}$ & i.p. & $100 \mathrm{mg} / \mathrm{kg} / \mathrm{d}$ & 15 days & ConA, LPS \\
\hline & ESPS & Root & LACA mice & $\begin{array}{l}\text { In } \\
\text { vivo }\end{array}$ & i.p. & $12.5,25,50,100 \mathrm{mg} / \mathrm{kg}$ & 4/9 days & - \\
\hline & PES & Root & $\begin{array}{l}\text { Female } \\
\text { C57BL/JCR }\end{array}$ & $\begin{array}{l}\text { In } \\
\text { vitro }\end{array}$ & s.c. & $100 \mathrm{mg} / \mathrm{kg}$ & 4 days & LPS \\
\hline & - & - & mice & - & - & - & - & - \\
\hline & - & - & - & - & - & - & - & - \\
\hline & ESPS & Root & Kunming mice & $\begin{array}{l}\text { In } \\
\text { vivo }\end{array}$ & i.g. & $25,50,100 \mathrm{mg} / \mathrm{kg}$ & 7 days & CD3+,CD4+, \\
\hline & - & - & - & - & - & - & - & CD8+ \\
\hline & - & - & - & - & - & - & - & - \\
\hline & ESPS & Root & Kunming mice & $\begin{array}{l}\text { In } \\
\text { vivo }\end{array}$ & i.g. & $25,50,100 \mathrm{mg} / \mathrm{kg}$ & 7 days & CD4+/CD8+, \\
\hline & - & - & - & - & - & - & - & IL-2 \\
\hline & ESPS & Root & BALB/c mice & $\begin{array}{l}\text { In } \\
\text { vivo }\end{array}$ & i.g. & $36,25,72.5,145 \mathrm{mg} / \mathrm{kg}$ & 14 days & - \\
\hline & - & - & - & - & - & - & - & - \\
\hline
\end{tabular}

Results $\begin{gathered}\text { Involved } \\ \text { Mechanism }\end{gathered}$

\begin{tabular}{|c|c|}
\hline- & - \\
\hline CD133 stem cells $\downarrow$ & Apoptosis \\
\hline $\begin{array}{l}\text { Immunity } \uparrow, \\
\text { hyperplasia of }\end{array}$ & Immunomodulation \\
\hline- & - \\
\hline
\end{tabular}

Chen et al.

The phagocytic function Immunomodulation $\quad \overline{\text { Xu (1983) }}$

of mice

Peritoneal

macrophages $\uparrow$

Sleep time $\uparrow$, number of Immunomodulation Chen (1984)

thymus $\downarrow$

Sleep time $\uparrow$, white blood Immunomodulation Chen (1984)

cells $\uparrow$

Formation of antibodies Immunomodulation Chen (1984)

in the spleen $\uparrow$

Strong phagocytosis $\uparrow \quad$ Immunoregulation Wang,

(1986)

proliferation

$(1986)$
-

Immunomodulation Xie (1989b)

secreting cells $\uparrow \mathrm{C} 57 \mathrm{BL} / 7$

mice delayed-type

hypersensitivity $\uparrow$

Humoral immune

response $\uparrow$

PES possesses Immunomodulation Shen et al.

mitogenic activities

Enhanced LPS,

lymphocyte

Transformations $\downarrow$

stimulates B-cells

The proliferation of

splenic

lymphocytes $\uparrow$,

$\mathrm{CD} 3+\mathrm{CD} 4+/$

$\mathrm{CD} 3+\mathrm{CD} 8+\uparrow$

The body's cellular Immunomodulation Luo (2013b)

immune

The phagocytic

function of

$-$

Immunomodulation (2020)

(Continued on following page) 
TABLE 3 | (Continued) Pharmacological activities and involved mechanism of ESPS.

\begin{tabular}{|c|c|c|c|c|c|c|c|c|c|c|c|}
\hline $\begin{array}{l}\text { Biological } \\
\text { activity }\end{array}$ & $\begin{array}{l}\text { Compound } \\
\text { Name }\end{array}$ & $\begin{array}{l}\text { Medical } \\
\text { Parts }\end{array}$ & Model & $\begin{array}{l}\text { Vivo/ } \\
\text { Vitro }\end{array}$ & $\begin{array}{c}\text { Administration } \\
\text { Route }^{\mathrm{a}}\end{array}$ & Dose & Duration & $\begin{array}{l}\text { Cytokine/ } \\
\text { Enzyme } \\
\text { /Protein }\end{array}$ & Results & $\begin{array}{l}\text { Involved } \\
\text { Mechanism }\end{array}$ & References \\
\hline & & & & & & & & & $\begin{array}{l}\text { immunosuppressed } \\
\text { mice } \uparrow\end{array}$ & & \\
\hline & ESPS & Root & BALB/c mice & $\begin{array}{l}\text { In } \\
\text { vivo }\end{array}$ & i.g. & $36,25,72.5,145 \mathrm{mg} / \mathrm{kg}$ & 7 days & - & 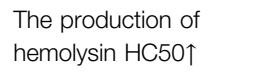 & Immunomodulation & Zhai (2020) \\
\hline & ESPS & Root & BALB/c mice & $\begin{array}{l}\text { In } \\
\text { vivo }\end{array}$ & i.g. & $36,25,72.5,145 \mathrm{mg} / \mathrm{kg}$ & 7 days & - & $\begin{array}{l}\text { The weight of the } \\
\text { thymus } \downarrow\end{array}$ & Immunomodulation & $\begin{array}{l}\text { Zhang, } \\
\text { (2015) }\end{array}$ \\
\hline & ESPS & Root & $\begin{array}{l}\text { BALB/c, DTH } \\
\text { mice }\end{array}$ & $\begin{array}{l}\text { In } \\
\text { vivo }\end{array}$ & i.g. & $36,25,72.5,145 \mathrm{mg} / \mathrm{kg}$ & 7 days & CD4+/CD8+ & $\begin{array}{l}\text { Immunosuppressive } \\
\text { effect }\end{array}$ & - & $\begin{array}{l}\text { Zhang, } \\
\text { (2015) }\end{array}$ \\
\hline & ESPS & Root & BALB/c mice & $\begin{array}{l}\text { In } \\
\text { vivo }\end{array}$ & i.g. & $36,25,72.5,145 \mathrm{mg} / \mathrm{kg}$ & 7 days & $\mathrm{IL}-2, \mathrm{IL}-4, \mathrm{IFN}-\gamma$ & Cytokine content $\downarrow$ & Cytokine expression & $\begin{array}{l}\text { Zhang, } \\
\text { (2015) }\end{array}$ \\
\hline & ESPS & Root & BALB/c mice & $\begin{array}{l}\text { In } \\
\text { vivo }\end{array}$ & i.g. & $36,25,72.5,145 \mathrm{mg} / \mathrm{kg}$ & 14 days & HC50 & $\begin{array}{l}\text { Sheep red blood cell } \\
\text { production }\end{array}$ & Immune stress & $\begin{array}{l}\text { Zhang, } \\
\text { (2015) }\end{array}$ \\
\hline & - & - & - & - & - & - & - & - & Hemolysin $\uparrow$ & - & - \\
\hline & ESPS & Root & $\begin{array}{l}\text { Weaned } \\
\text { piglets }\end{array}$ & $\begin{array}{l}\text { In } \\
\text { vitro }\end{array}$ & - & $\begin{array}{l}0,40,80,160 \\
320 \mu \mathrm{g} / \mathrm{ml}\end{array}$ & 21 days & $\begin{array}{l}\text { NO, iNOS, } \\
\text { NF-kB, }\end{array}$ & $\begin{array}{l}\text { Cooperate with ConA to } \\
\text { promote }\end{array}$ & Apoptosis & Han, (2013) \\
\hline & - & - & - & - & - & - & - & Th1 & T- cell proliferation & - & - \\
\hline & ESPS & Root & $\begin{array}{l}\text { Weaned } \\
\text { piglets }\end{array}$ & $\begin{array}{l}\text { In } \\
\text { vitro }\end{array}$ & - & 800 mg/kg & $14 d$ & IL-2,IL-6, TNF- $\alpha$, & Modulate the release of & Cytokine expression & $\begin{array}{l}\text { Han et al. } \\
\text { (2014) }\end{array}$ \\
\hline & - & - & - & - & - & - & - & $\alpha-A G P$ & $\begin{array}{l}\text { Pro-inflammatory } \\
\text { cytokines }\end{array}$ & - & - \\
\hline & ESPS & Root & ICR mice & $\begin{array}{l}\text { In } \\
\text { vivo }\end{array}$ & i.g. & $6,12,24 \mathrm{mg} / 10 \mathrm{~g} / \mathrm{d}$ & 21 days & TNF- $\alpha$, INF- $\gamma$ & $\begin{array}{l}\text { Regulate the serum } \\
\text { hemolysin level, }\end{array}$ & Apoptosis & $\begin{array}{l}\text { Sun et al. } \\
\text { (2018) }\end{array}$ \\
\hline & - & - & - & - & - & - & - & - & $\begin{array}{l}\text { Cell apoptosis } \downarrow \text { to } \\
\text { enhance the }\end{array}$ & - & - \\
\hline & - & - & - & - & - & - & - & - & $\begin{array}{l}\text { Body's humoral immune } \\
\text { function. }\end{array}$ & - & - \\
\hline & PES & Root & Mice & $\begin{array}{l}\text { In } \\
\text { vivo }\end{array}$ & i.p. & $125 \mathrm{mg} / \mathrm{kg} / \mathrm{d}$ & 5 days & BSAlgG $\uparrow$ & Enhance the defense. & Antioxidant index & $\begin{array}{l}\text { Zhu et al. } \\
\text { (1982) }\end{array}$ \\
\hline \multirow[t]{11}{*}{$\begin{array}{l}\text { Anti- } \\
\text { inflammatory }\end{array}$} & ESPS & Root & Kunming mice & $\begin{array}{l}\text { In } \\
\text { vivo }\end{array}$ & i.g. & $20 \mathrm{mg} / \mathrm{kg} / \mathrm{d}$ & 10 days & IL-1, IL-2, & $\begin{array}{l}\text { Improve immune } \\
\text { cytokines }\end{array}$ & Cytokine expression & $\begin{array}{l}\text { Meng, } \\
\text { (2018) }\end{array}$ \\
\hline & - & - & - & - & - & - & - & IL-10, TNF- $\alpha$ & - & - & - \\
\hline & ESPS & Root & BALB/c mice & $\begin{array}{l}\text { In } \\
\text { vivo }\end{array}$ & i.g. & $36.25,72.5,145 \mathrm{mg} / \mathrm{kg}$ & 7 days & $\begin{array}{l}\mathrm{IL}-1, \mathrm{IL}-1 \beta, \mathrm{IL}-2, \\
\mathrm{IL}-4\end{array}$ & $\begin{array}{l}\text { Number of enzymes } \\
\downarrow \text {,protect liver }\end{array}$ & Antioxidant index & $\begin{array}{l}\text { Zhang } \\
\text { (2018) }\end{array}$ \\
\hline & CASPs & Root & $\begin{array}{l}\text { Wistar male } \\
\text { rats }\end{array}$ & $\begin{array}{l}\ln \\
\text { vivo }\end{array}$ & i.g. & $50,100,200 \mathrm{mg} / \mathrm{kg}$ & $15 d$ & $\begin{array}{l}\mathrm{IL}-10 \uparrow, \mathrm{IL}-1 \beta \\
\text { TNF- } \downarrow \downarrow\end{array}$ & Inflammatory cytokines $\downarrow$ & - & $\begin{array}{l}\text { Xie et al. } \\
\text { (2015) }\end{array}$ \\
\hline & ESPS & Root & $\begin{array}{l}\text { Male BALB/c } \\
\text { mice }\end{array}$ & $\begin{array}{l}\text { In } \\
\text { vivo }\end{array}$ & i.g. & $14.5 \mathrm{mg} / \mathrm{ml} / \mathrm{d}$ & 7 days & IL-4, Cyclic GMP & $\begin{array}{l}\text { Improve the body's } \\
\text { immunity, }\end{array}$ & $\begin{array}{l}\text { Glutathione } \\
\text { metabolism, purine }\end{array}$ & Yang, (2016) \\
\hline & - & - & - & - & - & - & - & - & $\begin{array}{l}\text { Anti-inflammatory, } \\
\text { Antioxidant, }\end{array}$ & $\begin{array}{l}\text { Generation } \\
\text { metabolism, cysteine, }\end{array}$ & - \\
\hline & - & - & - & - & - & - & - & - & $\begin{array}{l}\text { and supply the body's } \\
\text { energy }\end{array}$ & $\begin{array}{l}\text { methionine metabolism } \\
\text { pathways }\end{array}$ & - \\
\hline & ASPS-1-1 & Root & $\begin{array}{l}\text { Male BALB/c } \\
\text { mice }\end{array}$ & $\begin{array}{l}\text { In } \\
\text { vivo }\end{array}$ & i.g. & $6.9 \mathrm{mg} / \mathrm{ml}$ & 7 days & $\begin{array}{l}\text { IL-1 } \beta, \text { TNF- } \alpha \\
\text { IL-2, }\end{array}$ & Liver cell damage $\downarrow$ & - & Yang, (2016) \\
\hline & ASPS-2-1 & - & - & - & - & $4.6 \mathrm{mg} / \mathrm{ml}$ & - & IL-4, IL-6 & - & - & - \\
\hline & ASPS-3-1 & - & - & - & - & $2.0 \mathrm{mg} / \mathrm{ml}$ & - & - & - & - & - \\
\hline & ESPS & Root & BALB/c mice & $\begin{array}{l}\text { In } \\
\text { vivo }\end{array}$ & i.g. & $36.25,72.5,145 \mathrm{mg} / \mathrm{kg}$ & 7 days & IL-2, IL-4, & $\begin{array}{l}\text { Secretion and } \\
\text { expression of }\end{array}$ & Cytokine expression & $\begin{array}{l}\text { Zhang } \\
\text { (2018) }\end{array}$ \\
\hline
\end{tabular}


TABLE 3 | (Continued) Pharmacological activities and involved mechanism of ESPS.

\begin{tabular}{|c|c|c|c|c|c|c|c|c|c|c|c|}
\hline $\begin{array}{l}\text { Biological } \\
\text { activity }\end{array}$ & $\begin{array}{l}\text { Compound } \\
\text { Name }\end{array}$ & $\begin{array}{l}\text { Medical } \\
\text { Parts }\end{array}$ & Model & $\begin{array}{l}\text { Vivo/ } \\
\text { Vitro }\end{array}$ & $\begin{array}{l}\text { Administration } \\
\text { Route }^{\mathrm{a}}\end{array}$ & Dose & Duration & $\begin{array}{l}\text { Cytokine/ } \\
\text { Enzyme } \\
\text { /Protein }\end{array}$ & Results & $\begin{array}{c}\text { Involved } \\
\text { Mechanism }\end{array}$ & References \\
\hline & - & - & - & - & - & - & - & - & inflammatory cytokines $\downarrow$ & - & - \\
\hline & ESPS & Root & BALB/c mice & $\begin{array}{l}\text { In } \\
\text { vivo }\end{array}$ & i.g. & $36.25,72.5,145 \mathrm{mg} / \mathrm{kg}$ & 7 days & $\begin{array}{l}\text { MDA, IL-1 } \beta \\
\text { TNF- } \alpha\end{array}$ & $\begin{array}{l}\text { The activity of } \\
\text { inflammatory }\end{array}$ & Cytokine expression & $\begin{array}{l}\text { Zhang et al. } \\
\text { (2019) }\end{array}$ \\
\hline & - & - & - & - & - & - & - & $\begin{array}{l}\text { NO, GSH- } \\
\text { Px, SOD, }\end{array}$ & $\begin{array}{l}\text { Cytokines, adhesion } \\
\text { factors } \downarrow \text {, }\end{array}$ & - & - \\
\hline & - & - & - & - & - & - & - & ICAM-1, iNOS, & $\begin{array}{l}\text { The secretion and } \\
\text { expression of }\end{array}$ & - & - \\
\hline & - & - & - & - & - & - & - & $N F-\kappa B$ & Inflammatory cytokines $\downarrow$ & - & - \\
\hline & ESPS & Root & KM mice & $\begin{array}{l}\text { In } \\
\text { vivo }\end{array}$ & i.g. & $14.5 \mathrm{mg} / \mathrm{ml} / \mathrm{d}$ & 7 days & IL-2, IL-6 & $\begin{array}{l}\text { By enhancing the body's } \\
\text { immune function, } \\
\text { scavenging free radicals, } \\
\text { liver cell apoptosis } \downarrow \text {, and } \\
\text { other mechanisms }\end{array}$ & $\begin{array}{l}\text { Bile secretion, Cysteine } \\
\text { metabolism, } \\
\text { Ubiquinone and other } \\
\text { terpenoid quinone } \\
\text { biosynthesis, Citrate } \\
\text { cycle regulating the } \\
\text { body's cytokines } \\
\text { Purine metabolism, } \\
\text { Riboflavin metabolism, } \\
\text { Primary bile acid } \\
\text { biosynthesis, } \\
\text { Biosynthesis of } \\
\text { unsaturated fatty acids, } \\
\text { Cysteine and } \\
\text { methionine metabolism }\end{array}$ & Lu (2016) \\
\hline \multirow[t]{7}{*}{$\begin{array}{l}\text { Anti- } \\
\text { leukemia }\end{array}$} & ESPS & Root & $\begin{array}{l}\text { Mice, L615 } \\
\text { cells }\end{array}$ & $\begin{array}{l}\text { In } \\
\text { vivo }\end{array}$ & i.p. & $0.34 \mathrm{~g} / \mathrm{kg} / \mathrm{d}$ & $5 d$ & - & $\begin{array}{l}\text { No significant effect on } \\
\text { survival time }\end{array}$ & Oxidative stress & Chen (1984) \\
\hline & ESPS & Root & $\begin{array}{l}\text { S801, S7811 } \\
\text { cells }\end{array}$ & $\begin{array}{l}\text { In } \\
\text { vitro }\end{array}$ & - & $10 \mu \mathrm{g} / \mathrm{ml}$ & single & - & $\begin{array}{l}\text { Improve the ability of } \\
\text { cells to produce } \\
\text { interferon }\end{array}$ & Oxidative stress & $\begin{array}{l}\text { Yang et al. } \\
\text { (1983) }\end{array}$ \\
\hline & ESPS & Root & $\begin{array}{l}\text { S801,S7811 } \\
\text { cells }\end{array}$ & $\begin{array}{l}\text { In } \\
\text { vitro }\end{array}$ & - & $10 \mu \mathrm{g} / \mathrm{ml}$ & single & - & $\begin{array}{l}\text { The life span of the } \\
\text { transcribed dry money } \\
\text { mRNA } \uparrow \text { or mRNA } \\
\text { inactivation rate } \downarrow\end{array}$ & Apoptosis & $\begin{array}{l}\text { Yang et al. } \\
\text { (1985) }\end{array}$ \\
\hline & ESPS & Root & K562 cells & $\begin{array}{l}\text { In } \\
\text { vitro }\end{array}$ & - & $\begin{array}{l}1,10,100,500 \\
1000 \mathrm{mg} / \mathrm{l}\end{array}$ & $24 \mathrm{~h}$ & - & Cell proliferation $\downarrow$ & Apoptosis & Tong (1994) \\
\hline & ESPS & Root & K562 cells & $\begin{array}{l}\text { In } \\
\text { vitro }\end{array}$ & - & $\begin{array}{l}0.405,0.810,1.620 \\
2.430,3.240 \mathrm{mg} / \mathrm{mL}\end{array}$ & $24 \mathrm{~h}$ & - & K562 cell apoptosis $\uparrow$ & Apoptosis & Luo (2008) \\
\hline & ASC-1 & Root & P-388 cells & $\begin{array}{l}\text { In } \\
\text { vitro }\end{array}$ & - & $35.69 \mu \mathrm{M}$ & single & - & $\begin{array}{l}\text { Mouse white blood cell } \\
\text { activity } \downarrow\end{array}$ & - & $\begin{array}{l}\text { Wang, } \\
\text { (2006) }\end{array}$ \\
\hline & $\mathrm{ASH}-1$ & - & - & - & - & $164.23 \mu \mathrm{M}$ & single & - & - & - & - \\
\hline \multirow[t]{4}{*}{$\begin{array}{l}\text { Anti- } \\
\text { oxidation }\end{array}$} & ESPS & Root & $. \mathrm{OH}, \mathrm{O}^{2-}$ & $\begin{array}{l}\text { In } \\
\text { vitro }\end{array}$ & - & $3 \mathrm{mg} / \mathrm{l}$ & single & - & Elimate $\cdot \mathrm{OH}$ and $\mathrm{O}^{2-}$ & Oxidative stress & $\begin{array}{l}\text { Meng et al. } \\
(2005)\end{array}$ \\
\hline & ESPS & Root & $. \mathrm{OH}, \mathrm{O}^{2-}$ & $\begin{array}{l}\text { In } \\
\text { vitro }\end{array}$ & - & 3 mg/l & single & - & Elimate $\cdot \mathrm{OH}$ and $\mathrm{O}^{2-}$ & Oxidative stress & Jiao, (2008) \\
\hline & - & - & - & - & - & - & - & - & $\begin{array}{l}\text { Inhibit lipid peroxidation } \\
\text { of red blood }\end{array}$ & - & - \\
\hline & $\overline{-}$ & - & - & - & - & - & - & - & cell membrane $\downarrow$ - & $\begin{array}{l}- \\
\text { stress }\end{array}$ & - \\
\hline
\end{tabular}


TABLE 3 | (Continued) Pharmacological activities and involved mechanism of ESPS.

\begin{tabular}{|c|c|c|c|c|c|c|c|c|c|c|c|}
\hline $\begin{array}{l}\text { Biological } \\
\text { activity }\end{array}$ & $\begin{array}{l}\text { Compound } \\
\text { Name }\end{array}$ & $\begin{array}{l}\text { Medical } \\
\text { Parts }\end{array}$ & Model & $\begin{array}{l}\text { Vivo/ } \\
\text { Vitro }\end{array}$ & $\begin{array}{l}\text { Administration } \\
\text { Route }^{\mathrm{a}}\end{array}$ & Dose & Duration & $\begin{array}{l}\text { Cytokine/ } \\
\text { Enzyme } \\
\text { /Protein }\end{array}$ & Results & $\begin{array}{l}\text { Involved } \\
\text { Mechanism }\end{array}$ & References \\
\hline & & & $\begin{array}{l}\text { Mice spleen } \\
\text { cells }\end{array}$ & $\begin{array}{l}\text { In } \\
\text { vitro }\end{array}$ & & & & & & & $\begin{array}{l}\text { Chen } \\
\text { (2011a) }\end{array}$ \\
\hline & ESPS & Root & $\begin{array}{l}\text { SD rats } \\
\text { hippocampal } \\
\text { neurons }\end{array}$ & $\begin{array}{l}\text { In } \\
\text { vitro }\end{array}$ & - & $1.25,2.5,5,10 \mathrm{~g} / \mathrm{ml}$ & 7 days & SOD,NOS,MDA & $\begin{array}{l}\text { Improve cell resistance } \\
\text { to oxidative stress } \\
\text { damage }\end{array}$ & $\begin{array}{l}\text { Bax expression } \downarrow, \mathrm{Bcl}-2 \\
\text { expression } \uparrow\end{array}$ & Diao (2008a) \\
\hline & ESPS & Root & $\begin{array}{l}\text { SD rats } \\
\text { hippocampal } \\
\text { neurons }\end{array}$ & $\begin{array}{l}\text { In } \\
\text { vitro }\end{array}$ & - & $1.25,2.5,5,10 \mu \mathrm{g} / \mathrm{ml}$ & 7 days & - & $\begin{array}{l}\text { Improve the anti- } \\
\text { apoptotic ability }\end{array}$ & $\begin{array}{l}\text { Bax expression } \downarrow, \mathrm{Bcl}-2 \\
\text { expression } \uparrow\end{array}$ & Diao (2008b) \\
\hline & ESPS & Root & $\begin{array}{l}\text { SD rats } \\
\text { hippocampal } \\
\text { neurons }\end{array}$ & $\begin{array}{l}\text { In } \\
\text { vitro }\end{array}$ & - & $1.25,2.5,5,10 \mu \mathrm{g} / \mathrm{ml}$ & 7 days & LDH,SOD,MDA & $\begin{array}{l}\text { Improve the anti- } \\
\text { apoptotic ability }\end{array}$ & P53 expression & Diao (2009a) \\
\hline & ESPS & Root & $\begin{array}{l}\text { SD rats } \\
\text { hippocampal }\end{array}$ & $\begin{array}{l}\text { In } \\
\text { vitro }\end{array}$ & - & $1.25,2.5,5,10 \mu \mathrm{g} / \mathrm{ml}$ & 7 days & $\begin{array}{l}\text { NO, iNOS } \\
\text { mRNA }\end{array}$ & $\begin{array}{l}\text { The expression of } \\
\text { iNOSmRNA } \downarrow\end{array}$ & $\begin{array}{l}\text { iNOSmRNA } \\
\text { expression }\end{array}$ & Diao (2008c) \\
\hline & ESPS & Root & $\begin{array}{l}\text { SD rats } \\
\text { hippocampal }\end{array}$ & $\begin{array}{l}\text { In } \\
\text { vitro }\end{array}$ & - & $1.25,2.5,5,10 \mu \mathrm{g} / \mathrm{ml}$ & 7 days & - & Anti-apoptotic ability $\uparrow$ & P53 expression $\downarrow$ & Diao (2009b) \\
\hline & ESPS & Root & $\begin{array}{l}\text { SD rats } \\
\text { hippocampal } \\
\text { neurons }\end{array}$ & $\begin{array}{l}\text { In } \\
\text { vitro }\end{array}$ & - & $1.25,2.5,5,10 \mu \mathrm{g} / \mathrm{ml}$ & 7 days & $\begin{array}{l}\text { SOD, CAT, } \\
\text { GSH-Px, MDA }\end{array}$ & Activity of Antioxidant $\uparrow$ & Antioxidant index & Diao (2008d) \\
\hline & ESPS & Root & $\begin{array}{l}\text { SD rats } \\
\text { hippocampal } \\
\text { neurons }\end{array}$ & $\begin{array}{l}\text { In } \\
\text { vitro }\end{array}$ & - & $1.25,2.5,5,10 \mu \mathrm{g} / \mathrm{ml}$ & 7 days & $\begin{array}{l}\text { MDA, ROS, } \\
\mathrm{H}_{2} \mathrm{O}_{2}\end{array}$ & $\begin{array}{l}\text { The content of oxygen } \\
\text { free radicals }\end{array}$ & Oxidative stress $\downarrow$ & Diao (2009c) \\
\hline & ESPS & Root & $\begin{array}{l}\text { SD rats } \\
\text { hippocampal } \\
\text { neurons }\end{array}$ & $\begin{array}{l}\text { In } \\
\text { vitro }\end{array}$ & - & $1.25,2.5,5,10 \mu \mathrm{g} / \mathrm{ml}$ & 7 days & $\begin{array}{l}\text { SOD, GSH-Px, } \\
\text { OGG1mRNA }\end{array}$ & $\begin{array}{l}\text { OGG1mRNA } \\
\text { expression } \uparrow\end{array}$ & $\begin{array}{l}\text { OGG1mRNA } \\
\text { expression }\end{array}$ & Diao (2009d) \\
\hline & CASPs & Root & $\begin{array}{l}\text { Wistar male } \\
\text { rats }\end{array}$ & $\begin{array}{l}\text { In } \\
\text { vitro }\end{array}$ & i.g. & $50,100,200 \mathrm{mg} / \mathrm{kg}$ & 15 days & $\begin{array}{l}\text { SOD, GSH- } \\
\text { Px } \uparrow, M D A \downarrow\end{array}$ & Oxidative damage $\downarrow$ & Oxidative stress & $\begin{array}{l}\text { Xie et al. } \\
(2015)\end{array}$ \\
\hline & ESPS & Root & $\begin{array}{l}\text { SD rats } \\
\text { hippocampal } \\
\text { neurons }\end{array}$ & $\begin{array}{l}\text { In } \\
\text { vitro }\end{array}$ & - & $2.5,5,10 \mu \mathrm{g} / \mathrm{ml}$ & 7 days & Fas, Fasıl $\downarrow$ & Cell apoptosis $\downarrow$ & Fas,Fasl $\downarrow$, Apoptosis & $\begin{array}{l}\text { Diao et al. } \\
\text { (2010a) }\end{array}$ \\
\hline & ESPS & Root & $\begin{array}{l}\text { SD rats } \\
\text { hippocampal } \\
\text { neurons }\end{array}$ & $\begin{array}{l}\text { In } \\
\text { vitro }\end{array}$ & - & $2.5,5,10 \mu \mathrm{g} / \mathrm{ml}$ & 7 days & - & $\begin{array}{l}\text { Gene expression } \downarrow \text {, the } \\
\text { activity } \uparrow\end{array}$ & C-fos,p53 expression & $\begin{array}{l}\text { Diao et al. } \\
\text { (2010b) }\end{array}$ \\
\hline & ESPS & Root & $\begin{array}{l}\text { SD rats } \\
\text { hippocampal } \\
\text { neurons }\end{array}$ & $\begin{array}{l}\text { In } \\
\text { vitro }\end{array}$ & - & $2.5,5,10 \mu \mathrm{g} / \mathrm{ml}$ & 7 days & $N F-\kappa B \downarrow$ & Gene expression $\downarrow$ & NF-кB pathways & $\begin{array}{l}\text { Diao et al. } \\
\text { (2010c) }\end{array}$ \\
\hline & ESPS & Root & $\begin{array}{l}\text { SD rats } \\
\text { hippocampal } \\
\text { neurons }\end{array}$ & $\begin{array}{l}\text { In } \\
\text { vitro }\end{array}$ & - & $\begin{array}{l}2.5,5,10 \mathrm{\mu g} / \mathrm{ml} \\
\text { Caspase-3 mRNA }\end{array}$ & $24 \mathrm{~h}$ & Caspase-3 & $\begin{array}{l}\text { Resist oxidative stress } \\
\text { damage }\end{array}$ & Oxidative stress & $\begin{array}{l}\text { Liu et al. } \\
\text { (2013) }\end{array}$ \\
\hline \multirow[t]{4}{*}{$\begin{array}{l}\text { Other } \\
\text { biological } \\
\text { activities }\end{array}$} & ESPS & Root & Kunming mice & $\begin{array}{l}\text { In } \\
\text { vivo }\end{array}$ & - & 300 mg/kg & 14 days & $\begin{array}{l}\text { DAO, occludin- } \\
1 \text {, zonula } \\
\text { occludens-1 }\end{array}$ & $\begin{array}{l}\text { Improves intestinal } \\
\text { integrity }\end{array}$ & $\begin{array}{l}\text { TLR4/NF-kB signaling } \\
\text { pathway }\end{array}$ & $\begin{array}{l}\text { Han et al. } \\
\text { (2016a) }\end{array}$ \\
\hline & ESPS & Root & Kunming mice & $\begin{array}{l}\text { In } \\
\text { vivo }\end{array}$ & i.g. & 300 mg/kg & 14 days & $\begin{array}{l}\text { Occludin-1, } \\
\text { HSP7O }\end{array}$ & $\begin{array}{l}\text { Gene mRNA expression } \\
\text { of epidermal growth } \\
\text { factor and its receptor } \uparrow\end{array}$ & mRNA expression & $\begin{array}{l}\text { Han et al. } \\
\text { (2016b) }\end{array}$ \\
\hline & ESPS & Root & $\begin{array}{l}\text { Male } \\
\text { Wistar rat }\end{array}$ & $\begin{array}{l}\text { In } \\
\text { vivo }\end{array}$ & i.g. & $50,100,200 \mathrm{mg} / \mathrm{kg}$ & 10 days & - & $\begin{array}{l}\text { Protect the body weight } \\
\text { of irradiated rats }\end{array}$ & - & Mo (2012a) \\
\hline & ESPS & Root & & & i.g. & $50,100,200 \mathrm{mg} / \mathrm{kg}$ & 10 days & WBC, RBC, PLT & & - & Mo (2012b) \\
\hline
\end{tabular}

(Continued on following page) 
TABLE 3 | (Continued) Pharmacological activities and involved mechanism of ESPS.

\begin{tabular}{|c|c|c|c|c|c|c|c|c|c|c|c|}
\hline $\begin{array}{l}\text { Biological } \\
\text { activity }\end{array}$ & $\begin{array}{l}\text { Compound } \\
\text { Name }\end{array}$ & $\begin{array}{l}\text { Medical } \\
\text { Parts }\end{array}$ & Model & $\begin{array}{l}\text { Vivo/ } \\
\text { Vitro }\end{array}$ & $\begin{array}{l}\text { Administration } \\
\text { Route }^{\mathrm{a}}\end{array}$ & Dose & Duration & $\begin{array}{l}\text { Cytokine/ } \\
\text { Enzyme } \\
\text { /Protein }\end{array}$ & Results & $\begin{array}{l}\text { Involved } \\
\text { Mechanism }\end{array}$ & References \\
\hline & & & $\begin{array}{l}\text { Male } \\
\text { Wistar rat }\end{array}$ & $\begin{array}{l}\text { In } \\
\text { vivo }\end{array}$ & & & & & $\begin{array}{l}\text { Protect peripheral blood } \\
\text { cells from radiation } \\
\text { exposure }\end{array}$ & & \\
\hline & ESPS & Root & Adult flies & $\begin{array}{l}\text { In } \\
\text { vivo }\end{array}$ & i.g. & $15,30 \mathrm{mg} / \mathrm{ml}$ & 5 days & - & $\begin{array}{l}\text { Protects the intestinal } \\
\text { tract from DSS }\end{array}$ & $\begin{array}{l}\text { EGFR, JNK, Notch } \\
\text { pathways }\end{array}$ & $\begin{array}{l}\text { Zhang et al. } \\
\text { (2020a) }\end{array}$ \\
\hline & ESPS & Root & BALB/C mice & $\begin{array}{l}\text { In } \\
\text { vivo }\end{array}$ & i.g. & 300 mg/kg & 7 days & $\begin{array}{l}\text { MLCK, TJ, NF- } \\
\kappa B, \text { LPS }\end{array}$ & $\begin{array}{l}\text { Associated with } \\
\text { inhibition of the NF-KB/ } \\
\text { MLCK pathway }\end{array}$ & NF-кB/MLCK pathway & $\begin{array}{l}\text { Han et al. } \\
(2017)\end{array}$ \\
\hline & ESPS & Root & Kunming mice & $\begin{array}{l}\text { In } \\
\text { vivo }\end{array}$ & i.g. & $50,100,200 \mathrm{mg} / \mathrm{kg}$ & 7 days & $\begin{array}{l}\text { IL-6, TNF- } \alpha \\
\text { IL- } 1 \beta\end{array}$ & $\begin{array}{l}\text { Improve immune organ } \\
\text { index and regulate } \\
\text { cytokine levels }\end{array}$ & - & Pan (2019b) \\
\hline & ESPS & Root & Male SD rat & $\begin{array}{l}\text { In } \\
\text { vivo }\end{array}$ & i.g. & $100 \mathrm{mg} / \mathrm{kg}$ & 20 days & - & $\begin{array}{l}\text { Neuroprotection, anti- } \\
\text { apoptosis }\end{array}$ & Anti-apoptosis & Lu (2015) \\
\hline & ESPS & Root & $\begin{array}{l}\text { Male kunming } \\
\text { mice }\end{array}$ & $\begin{array}{l}\text { In } \\
\text { vivo }\end{array}$ & i.g. & $450,150 \mathrm{mg} / \mathrm{kg} / \mathrm{d}$ & 14 days & - & $\begin{array}{l}\text { Ameliorate energy } \\
\text { metabolism, creatinine, } \\
\text { improve the level of } \\
\text { serum the breakdown of } \\
\text { protein } \downarrow \text { free radical } \\
\text { content of the body }\end{array}$ & Energy metabolism & Han, (2007) \\
\hline & ESPS & Root & Kunming mice & $\begin{array}{l}\text { In } \\
\text { vivo }\end{array}$ & i.g. & $50,100,200 \mathrm{mg} / \mathrm{kg} / \mathrm{d}$ & 5 days & IL-6, TNF- $\alpha$ & $\begin{array}{l}\text { Inhibit swelling, improve } \\
\text { immune organs, immune } \\
\text { cytokines }\end{array}$ & Immunomodulation & $\begin{array}{l}\text { Meng, } \\
(2018)\end{array}$ \\
\hline & ESPS & Root & Female SD rat & $\begin{array}{l}\text { In } \\
\text { vivo }\end{array}$ & s.c. & $100 \mathrm{mg} / \mathrm{kg} / \mathrm{d}$ & $2 / 5$ days & $\begin{array}{l}\text { sICAM-1, TGF- } \\
\beta 1, \text { LYM, RT, } \\
\text { GLU, LDH }\end{array}$ & Improve pleural effusion & Immunomodulation & $\begin{array}{l}\text { Meng, } \\
(2018)\end{array}$ \\
\hline & ESPS & Root & Kunming mice & $\begin{array}{l}\text { In } \\
\text { vivo }\end{array}$ & i.g. & $50,100,200 \mathrm{mg} / \mathrm{kg} / \mathrm{d}$ & 7 days & IL-1 $\beta$, TNF- $\alpha$ & $\begin{array}{l}\text { Improve immune organs, } \\
\text { immune cytokines }\end{array}$ & Immunomodulation & $\begin{array}{l}\text { Meng, } \\
(2018)\end{array}$ \\
\hline & ASP & Root & $\begin{array}{l}\text { Male Wistar } \\
\text { rats }\end{array}$ & $\begin{array}{l}\text { In } \\
\text { vivo }\end{array}$ & i.g. & 200 mg/kg & 28 days & $\begin{array}{l}\text { SOD, GPX, TC, } \\
\text { TG, TBARS }\end{array}$ & $\begin{array}{l}\text { Adjust the } \\
\text { pathophysiological }\end{array}$ & $\begin{array}{l}\text { Antioxidant index } \\
\text { parameters of diabetic } \\
\text { rats }\end{array}$ & $\begin{array}{l}\text { Fu et al. } \\
\text { (2012) }\end{array}$ \\
\hline & ESPS & Root & Kunming mice & $\begin{array}{l}\text { In } \\
\text { vivo }\end{array}$ & i.g. & $50,100,200 \mathrm{mg} / \mathrm{kg}$ & 5 days & SOD, GSH-PX, & $\begin{array}{l}\text { Improve the Antioxidant } \\
\text { capacity CAT, MDA }\end{array}$ & $\begin{array}{l}\text { Antioxidant index } \\
\text { caused by D-Gal }\end{array}$ & $\begin{array}{l}\text { Meng, } \\
\text { (2018) }\end{array}$ \\
\hline & ESPS & Root & Female SD rat & $\begin{array}{l}\text { In } \\
\text { vivo }\end{array}$ & i.p. & $50,100,200 \mathrm{mg} / \mathrm{kg} / \mathrm{d}$ & 5 days & $\begin{array}{l}\text { SOD, MDA, } \\
\text { AChE, ChAT }\end{array}$ & $\begin{array}{l}\text { Regulate enzyme activity } \\
\text { in brain tissue and serum }\end{array}$ & Immunomodulation & $\begin{array}{l}\text { Meng, } \\
\text { (2018) }\end{array}$ \\
\hline & ANP & Buds & $\begin{array}{l}\text { RAW-Blue TM } \\
\text { cells }\end{array}$ & $\begin{array}{l}\text { In } \\
\text { vitro }\end{array}$ & - & - & - & - & $\begin{array}{l}\text { Promoted by the } \\
\text { interaction through }\end{array}$ & - & $\begin{array}{l}\text { Lee et al. } \\
\text { (2015) }\end{array}$ \\
\hline & AAP & - & (RAW 264.7) & - & - & - & - & - & the membrane receptors & - & - \\
\hline & PEA & Root & - & $\begin{array}{l}\text { In } \\
\text { vitro }\end{array}$ & i.g. & $1.75 \mathrm{~g} / \mathrm{kg}$ & $24 \mathrm{~h}$ & CRP & $\begin{array}{l}\text { Suppress } \\
\text { hypoglycemia and }\end{array}$ & $\begin{array}{l}\text { Inflammation } \\
\text { inflammation to relieve } \\
\text { alcohol }\end{array}$ & $\begin{array}{l}\text { Bang et al. } \\
\text { (2015) }\end{array}$ \\
\hline
\end{tabular}

${ }^{a}$ i. g. intragastric administration; i. v. intravenous injection; i. p. intraperitoneal injection; s. c. subcutaneous injection. 
Figure 3 summarize the biological activities and related mechanism of ESPS, respectively.

\section{CONCLUSIONS AND FUTURE PERSPECTIVES}

Consult the related literature and data about E. senticosus, we can find that the related studies mainly focused on small molecule components, which ignored macromolecular substances such as protein, polysaccharides, pectin, and cellulose. As the effective ingredient of E. senticosus, polysaccharide possess a wide range of pharmacological effects with the advantages of non-toxic, twoway immune regulation, and has great potential for clinical application. However, research on polysaccharides has increased resistance due to its high molecular weight, complex structure, low content, difficulty of separation and low purity. The research work of its future perspectives is mainly reflected in the following aspects.

1) From aspects of efficient extraction, the existing methods expose the disadvantages of low yield and long extraction time, and therefore cannot be industrialized in mass production. Instead, a wide range of green environmental technologies such assisted extraction with enzymes and chelating agents have not been studied and applied in the extraction of ESPS.

2) As for the resource utilization, the residues of herbs and fruits after extraction of small molecules are rich in a large number of macromolecular substances, such as pectin, polysaccharides and cellulose. Thus, recirculated extraction is conducive to the sustainable development and maximum utilization of traditional Chinese medicine. It has been reported that relative high yield of sugars and pectin was separately extracted from residues of Ginseng (Zhang et al., 2020b) and Sweet Potato Peels (Hamidon et al., 2020). Meanwhile, Chen et al. found that a large amount of ESPS could be extracted from petioles, leaves and fruits (Chen, 2009). However, no literature on the reuse and expansion of $E$. senticosus resource were found. Collectively, extraction of ESPS from the residue and other medical parts will provide us future research direction.

\section{REFERENCES}

Bai, Y. M. (2015). Study on Separation, Purification and Structure of Acanthopanax Senticosus Polysaccharide. Northeast Normal University.

Bang, J. S., Chung, Y. H., Chung, S. J., Lee, H. S., Song, E. H., Shin, Y. K., et al. (2015). Clinical Effect of a Polysaccharide-Rich Extract of Acanthopanax Senticosus on Alcohol Hangover. Pharmazie 70 (4), 269-273. doi:10.1691/ph.2015.4786

Cao, G. W., and Du, P. (1993).Astragalus Polysaccharides, Acanthopanax Senticosus Polysaccharides and Lycium Barbarum Polysaccharides Regulate the Anti-tumor Activity of LAK Cells In Vivo. J. Second Mil. Med. Univ. 14 (1), 10-13.

Chen, F. F. (2015). Study on the Extraction Process of Acanthopanax Senticosus Polysaccharide. Beijing, China: China Feed 2015 (1), 22-24. doi:10.15906/ j.cnki.cn11-2975/s.20150106
3) Recently, the rapid development and application of biological macromolecules in new drug delivery system and edible film provide people new directions and technologies for pharmaceutical and food preservation. If ESPS could pack or interact with other ingredients (flavonoids, saponins, protein) and then act as drug delivery system is relatively empty areas.

4) At present, several products derived from E. senticosus such as capsules, wine and tea have long been developed and marketed in view of their excellent health-care function and clinical therapeutic effect. However, ESPS has not been put into clinical use in view of the absence of quality control standards and reference substance. How to establish a comprehensive quality management system is a problem worth thinking about.

In conclusion, health has received more and more attention with the development of science and the improvement of living standard, and the exploitation of functional food has become a research hotspot and development trend. E. senticosus, a homology of medicine and food as the main raw materials, has displayed the most economic and developing value. Meanwhile, the emergence of ESPS can better inherit, innovate and develop traditional Chinese medicine culture and products. It is believed that ESPS will be widely applied soon in the fields of clinical and functional food with the deepening of research and the maturity of technology.

\section{AUTHOR CONTRIBUTIONS}

XL: Investigation, Resources, Writing-original draft. CC: Writing-original draft. JQ: Conceptualization, Writing-review and editing, Funding acquisition. AL: Writing-review and editing, Funding acquisition.

\section{FUNDING}

This work was financially supported by grants from National Natural Science Foundation of China (No. 81703675), China Postdoctoral Science Foundation (2021M692398) and Natural Science Foundation of Liaoning Province (No. 2019-ZD-0631 and 2019-ZD-0914).

Chen, H. T. (2011). Studies on the Extraction and Purification Techniques of Polysaccharides from Acathopanax Senticosus. JOURNAL JIAMUSI UNIVERSITY(NATURAL SCIENCE EDITION) 29 (02), 311-313. doi:10.3969/ j.issn.1008-1402.2011.02.04610.7202/1012856ar

Chen, J. E. (2015). Optimization of Ultrasound-Assisted Extraction of Manyprickle Acathopanax Root Polysaccharides Using Response Surface Methodology. North. Hortic. (07), 123-127. doi:10.11937/bfyy.201507036

Chen, J. Y., Yu, S. J., and Xiao, D. (2019). The Effection of Acanthopanax Senticosus Polysaccharide on Cancer Stem Cells. Chin. J. Lab. Diagn. 23 (07), 1233-1238. doi:10.3969/j.issn.1007-4287.2019.07.04410.1177/ 1071100719879438

Chen, K., M. (2009). Delirium und Wahn. Psychiat Prax, 36 (02), 98-99. Ankang, China: J. Ankang Univ. doi:10.3969/j.issn.1674-0092.2009.02.03110.1055/s0029-1220834 
Chen, L., and Huang, G. (2018). Antitumor Activity of Polysaccharides: An Overview. Curr. Drug Targets 19 (1), 89-96. doi:10.2174/ 1389450118666170704143018

Chen, R., Liu, Z., Zhao, J., Chen, R., Meng, F., Zhang, M., et al. (2011). Antioxidant and Immunobiological Activity of Water-Soluble Polysaccharide Fractions Purified from Acanthopanax Senticosu. Food Chem. 127 (2), 434-440. doi:10.1016/j.foodchem.2010.12.143

Chen, R. Z. (2011). Study on Separation, Purification and Antioxidant and Immune Activity of Acanthopanax Senticosus Polysaccharide. Indonesia: Bali Island.

Chen, X. J. (1984). The Anti-tumor and Immune Effects of Acanthopanax Senticosus Polysaccharide. Cancer 3 (3), 191-193.

Chen, Y., Zhang, J., Li, Q., Wu, J., Sun, F., Liu, Z., et al. (2018). Response Surface Methodology for Optimizing the Ultrasound-Assisted Extraction of Polysaccharides from Acanthopanax Giraldii. Chem. Pharm. Bull. (Tokyo) 66 (8), 785-793. doi:10.1248/cpb.c18-00030

Cui, N. (2012). Research Review on Polysaccharides in Traditional Chinese Drug. QILU PHARMACEUTICAL AFFAIRS 31 (11), 659-662.

Diao, B. (2008). A Study on the Antioxidative Effect of Acanthopanacis Senticosi Polysaccharides. THE JOURNAL PRACTICAL MEDICINE 22 (01), 1102-1104. doi:10.3969/j.issn.1006-5725.2008.07.008

Diao, B. (2009). Effect of Acanthopanacis Senticosi Polysaccharides on Oxygen Free Radical in Hippocampal Neures Impaired by $\mathrm{H} 2 \mathrm{O} 2$. CHINESE JOURNAL HOSPITAL PHARMACY 29 (01), 7-11. doi:10.3321/j.issn:10015213.2009.01.003

Diao, B. (2009). Effect of Acanthopanax Senticosus Polysaccharide on H_2O_2 Induced Apoptosis of Hippocampal Neurons and Apoptosis Genes. Guangdong Med. 30 (01), 35-36. doi:10.3969/j.issn.1001-9448.2009.01.015

Diao, B. (2009). Effects of Acanthopanacis Senticosi Polysaccharides on Antioxidant Enzyme System in Hippocampal Neurons. HERALD MEDICINE 28 (01), 21-24. doi:10.3870/yydb.2009.01.006

Diao, B. (2008). Effects of Acanthopanacis Senticosi Polysaccharides on Expression of iNOS mRNA in Hippocampal Neurons Damaged by Oxidative Stress. MILITARY MEDICAL JOURNAL SOUTH CHINA 19 (11), 15-17.

Diao, B. (2009). Effects of Acanthopanacis Senticosi Polysaccharides on Expression of OGG1 mRNA in Hippocampal Neurons Damaged by Oxidative Stress. CHINESE JOURNAL GERONTOLOGY 29 (04), 396-399. doi:10.3969/ j.issn.1005-9202.2009.04.005

Diao, B. (2008). Effects of Acanthopanacis Senticosi Polysaccharides on Oxidative Stress Damage and Bcl-2 Family in Hippocampal Neurons Impaired by $\mathrm{H} 2 \mathrm{O} 2$. LISHIZHEN MEDICINE MATERIA MEDICA RESEARCH 24 (7), 2705-2707. doi:10.3969/j.issn.1008-0805.2008.11.061

Diao, B. (2008). Protective Effect of Acanthopanax Senticosus Polysaccharide on H_2O_2 Induced Apoptosis of Hippocampal Cells. South China Natl. Defense Med. J. 22 (4), 4-6+17.

Diao, B., Tang, Y., and Zhu, Y. L. (2010). Effect of Acanthopanax Senticosus Polysaccharide on the Expression of Fas and Fasl in Hippocampal Neurons Injured by H_2O_2. Chin. J. Clin. Neurosurg. 15 (07), 416-418. doi:10.3969/ j.issn.1009-153X.2010.07.010

Diao, B., Tang, Y., and Zhu, Y. L. (2010). The Effect of Acanthopanax Senticosus Polysaccharide on the Expression of C-Fos and P53 Genes in Hippocampal Neurons Injured by H_2O_2. Chin. J. Clin. Neurosurg. 15 (06), 347-349. doi:10.3969/j.issn.1009-153X.2010.06.010

Diao, B., Tang, Y., and Zhu, Y. L. (2010). The Effect of Acanthopanax Senticosus Polysaccharide on the Expression of NF-Kb in Hippocampal Neurons Injured by H_2O_2. Chin. J. Clin. Neurosurg. 15 (06), 350-352. doi:10.3969/j.issn.1009153X.2010.06.011

Duan, X. L. (2015). Research Progress of Acanthopanax Senticosus' Immunomodulatory Function. Chin. J. Traditional Vet. Sci. 2015 (6), 72-75. doi:10.3969/j.issn.1003-8655.2015.06.043

Feng, Y. (2016). Study on Optimizing Extraction Conditions of Acanthopanax Senticosus Polysaccharide by Single Factor Test. Shandong J. Anim. Sci. Vet. Med. 37 (08), 8-9. doi:10.3969/j.issn.1007-1733.2016.08.004

Fu, J., Fu, J., Yuan, J., Zhang, N., Gao, B., Fu, G., et al. (2012). Anti-diabetic Activities of Acanthopanax Senticosus Polysaccharide (ASP) in Combination with Metformin. Int. J. Biol. Macromol 50 (3), 619-623. doi:10.1016/ j.ijbiomac.2012.01.034

Ganesan, K., and Xu, B. (2019). Anti-Diabetic Effects and Mechanisms of Dietary Polysaccharides. Molecules 24 (14). doi:10.3390/molecules24142556
Gao, Y. Y. (2019). Research Progress on Chemical Constituents and Pharmacological Effects of Acanthopanax Senticosus. Inf. Traditional Chin. Med. 36 (02), 113-116. doi:10.19656/j.cnki.1002-2406.190060

Hamidon, N. H., Abang Zaidel, D. N., and Mohd Jusoh, Y. M. (2020). Optimization of Pectin Extraction from Sweet Potato Peels Using Citric Acid and its Emulsifying Properties. Recent Pat Food Nutr. Agric. 11 (3), 202-210. doi:10.2174/2212798411666200207102051

Han, J., Bian, L., Liu, X., Zhang, F., Zhang, Y., and Yu, N. (2014). Effects of Acanthopanax Senticosus Polysaccharide Supplementation on Growth Performance, Immunity, Blood Parameters and Expression of Proinflammatory Cytokines Genes in Challenged Weaned Piglets. Asianaustralas J. Anim. Sci. 27 (7), 1035-1043. doi:10.5713/ajas.2013.13659

Han, J., Li, J. H., Bai, G., Shen, G. S., Chen, J., Liu, J. N., et al. (2017). Acanthopanax Senticosus Polysaccharides-Induced Intestinal Tight junction Injury Alleviation via Inhibition of NF-Kb/MLCK Pathway in a Mouse Endotoxemia Model. World J. Gastroenterol. 23 (12), 2175-2184. doi:10.3748/wjg.v23.i12.2175

Han, J., Liu, L., Yu, N., Chen, J., Liu, B., Yang, D., et al. (2016). Polysaccharides from Acanthopanax Senticosus Enhances Intestinal Integrity through Inhibiting TLR4/NF-Kb Signaling Pathways in Lipopolysaccharide-Challenged Mice. Anim. Sci. J. 87 (8), 1011-1018. doi:10.1111/asj.12528

Han, J., Xu, Y., Yang, D., Yu, N., Bai, Z., and Bian, L. (2016). Effect of Polysaccharides from Acanthopanax Senticosus on Intestinal Mucosal Barrier of Escherichia coli Lipopolysaccharide Challenged Mice. Asianaustralas J. Anim. Sci. 29 (1), 134-141. doi:10.5713/ajas.15.0534

Han, J. (2013). Study on the Regulation and Mechanism of Acanthopanax Senticosus Polysaccharide on Immune Function of Weaned Piglets. Shenyang, China: Shenyang Agricultural University.

Han, S. B., Yoon, Y. D., Ahn, H. J., Lee, H. S., Lee, C. W., Yoon, W. K., et al. (2003). Toll-like Receptor-Mediated Activation of B Cells and Macrophages by Polysaccharide Isolated from Cell Culture of Acanthopanax Senticosus. Int. Immunopharmacol 3 (9), 1301-1312. doi:10.1016/s1567-5769(03)00118-8

Han, X. G. (2007). Changes in Blood Biochemical Indicators of Loaded-Swimming Mice after the Intervention of Acanthopanax Root Polysaccharides. JOURNAL CLINICAL REHABILITATIVE TISSUE ENGINEERING RESEARCH 11 (51), 10300-10303. doi:10.3321/j.issn:1673-8225.2007.51.034

Hao, C. Y., and Nan, J. X. (2013). Research Progress of Acanthopanax Senticosus against Liver Injury. J. Jilin Med. Coll. 34 (02), 112-115. doi:10.3969/j.issn.16732995.2013.02.015

Hu, H., Liang, H., and Wu, Y. (2015). Isolation, Purification and Structural Characterization of Polysaccharide from Acanthopanax Brachypus. Carbohydr. Polym. 127, 94-100. doi:10.1016/j.carbpol.2015.03.066

Jiang, Y., Jiang, T., T., and Yue, N. (2017). Extraction of Polysaccharide from Lemon by Alkaline Solution. Chem. World 58 (05), 257-261. doi:10.11882/ j.issn.0254-5071.2018.10.031

Jiao, Y. (2008). Study on Extraction of Acanthopanax Senticosus Polysaccharide and its Antioxidant Activity. Changchun, China: Jilin University.

Jin, W. (2016). Acanthopanax Senticosus Polysaccharide Down-Regulates Survivin Protein Expression and Induces HeLa Cell Apoptosis. Chin. Traditional Patent Med. 38 (04), 902-904. doi:10.3969/j.issn.1001-1528.2016.04.040

Jin, W. (2014). Experimental Study of Acanthopanax Senticosus Polysaccharide on the Proliferation and Apoptosis of Human Cervical Cancer HeLa Cells In Vitro. Chin. Traditional Patent Med. 36 (01), 162-164.

Lee, D., Park, J., Yoon, J., Kim, M. Y., Choi, H. Y., and Kim, H. (2012). Neuroprotective Effects of Eleutherococcus Senticosus Bark on Transient Global Cerebral Ischemia in Rats. J. Ethnopharmacol 139 (1), 6-11. doi:10.1016/j.jep.2011.05.024

Lee, J. B., Tanikawa, T., Hayashi, K., Asagi, M., Kasahara, Y., and Hayashi, T. (2015). Characterization and Biological Effects of Two Polysaccharides Isolated from Acanthopanax Sciadophylloides. Carbohydr. Polym. 116, 159-166. doi:10.1016/j.carbpol.2014.04.013

Li, F. R., and Liu, B. (2003). Microwave Extraction and Content Determination of Acanthopanax Senticosus Polysaccharide. XINIIANG JOURNAL TRADITIONAL CHINESE MEDICINE 21 (1), 11-12. doi:10.3969/j.issn.1009-3931.2003.01.009

Li, L. H. (2019). Study on the Extraction Technology for Acanthopanax Senticosus Polysaccharide. Feed Res. 42 (06), 93-96. doi:10.13557/j.cnki.issn1002-2813.2019.06.026

Li, X., J. (2018). Extraction Process Optimization of Acidic tuckahoe Polysaccharides. China Brewing 37 (10), 158-161. doi:10.11882/j.issn.02545071.2018.10.031 
Li, X. H. (2020). The Effect of Graded Alcohol Precipitation of Acanthopanax Senticosus Polysaccharide at Different Concentrations on Mouse Spleen Cell Proliferation and IL-2 Expression. Heilongjiang Anim. Sci. Vet. Med. 2020 (5), 127-130+133. doi:10.13881/j.cnki.hljxmsy.2019.06.0286

Li, Y. P., and Zhou, H. L. (2020). Acidic Extraction and Antioxidant Activity of Polysaccharides from Corn Silk. Cereals \& Oils 33 (08), 86-90. doi:10.3969/ j.issn.1008-9578.2020.08.024

Liu, Y. (2010). Extraction, Separation and Micronization of the Main Active Components of Acanthopanax Senticosus. Harbin, China: Northeast Forestry University.

Liu, Y., Huang, Q. C., and Cao, J. H. (2013). The Protective Effect of Acanthopanax Senticosus Polysaccharide on H_2O_2 Induced Apoptosis of Rat Hippocampal Neurons. Chin. J. Clin. Neurosurg. 18 (11), 681-683.

Long, L. N., Zhang, H. H., Wang, F., Yin, Y. X., Yang, L. Y., and Chen, J. S. (2021). Research Note: Effects of Polysaccharide-Enriched Acanthopanax Senticosus Extract on Growth Performance, Immune Function, Antioxidation, and Ileal Microbial Populations in Broiler Chickens. Poult. Sci. 100 (4), 101028. doi:10.1016/j.psj.2021.101028

Lu, F. (2015). Application of Metabonomics Method to Identify Possible Effect of Acanthopanax Senticosus Polysaccharide on AD. Chin. J. Exp. Traditional Med. Formulae 21 (22), 150-153. doi:10.13422/ j.cnki.syfjx. 2015220150

Lu, F. (2016). Investigation of Protective Effect of Acanthopanax Senticosus Polysaccharides on Immunological Liver Injury in Mice by Metabolomics Methods. New Chin. Med. Clin. Pharmacol. 27 (06), 823-829. doi:10.19378/ j.issn.1003-9783.2016.06.016

Luan, J. G. (2012). A Precious Medicinal and Edible Plant-Acanthopanax Senticosus. New Agric. 2012 (15), 53-54. doi:10.3969/j.issn.10024298.2012.15.074

Luo, Q. (2013). Effects of Acanthopanax Senticosus Polysaccharide on Immune Function of normal Mice. Heilongjiang Anim. Sci. Vet. Med. (13), 120-122. doi:10.13881/j.cnki.hljxmsy.2013.13.052

Luo, Q. (2013). Effects of Acanthopanax Senticosus Polysaccharide on Lymphocyte Transformation Rate and Peripheral Lymphocyte Subsets in Normal Mice. J. Henan Agric. Sci. 42 (08), 137-140. doi:10.3969/ j.issn.1004-3268.2013.08.034

Luo, Q. (2008).Study on Cell K562 Apoptosis Induced by Acanthopanax Senticosus In Vitro. JOURNAL HEBEI NORTH UNIVERSITY(MEDICAL EDITION) 05, 17-19.

Meng, Q., Pan, J., Liu, Y., Chen, L., and Ren, Y. (2018). Anti-tumour Effects of Polysaccharide Extracted from Acanthopanax Senticosus and Cell-Mediated Immunity. Exp. Ther. Med. 15 (2), 1694-1701. doi:10.3892/etm.2017.5568

Meng, Q. F., Yu, X. K., Xu, M. Y., Li, M. L., Gao, Z. H., Fan, H., et al. (2005). Extraction of Acanthopanacis Senticosi Polysaccharides and Their Antioxidative Effect. J. Jilin Univ. Inf. Sci. Ed. 43 (5), 683-686. doi:10.3321/ j.issn:1671-5489.2005.05.031

Meng, Q. L. (2018). Basic Pharmacological Research on the Development of Changbai Mountain Acanthopanax Senticosus Polysaccharide. Changchun, China: Jilin Agricultural University.

Mo, L. F. (2012). Protective Effect of Acanthopanax Senticosus Polysaccharide on the Gastrointestinal Tract and Reproductive System of Rats Irradiated by $(60)$ Co $\gamma$ Rays. China Radiat. Health 21 (2), 153-155. doi:10.3760/cma.j.issn.10096906.2012.01.004

Mo, L. F. (2012). Protective Effects of Acanthepanax Senticosus Polysaccharide on Gastrointestinal and Reproductive System of 60Co $\gamma$-ray Irradiated Rats. Chin. J. Nautical Med. Hyperb. Med. (01), 17-20.

Pan, J. Z. (2019). Research Progress on Chemical Constituents and Pharmacological Activities of Acanthopanax Senticosus. Sci. Tech. Food Industry 40 (23), 353-360. doi:10.13386/j.issn1002-0306.2019.23.058

Pan, J. Z. (2019). Study on analgesic and anti-inflammatory effect and immunoregulatory mechanism of polysaccharides in Radix et Caulis Acanthopanacis Senticosi. Shanghai J. Traditional Chin. Med. 53 (10), 74-82. doi:10.16305/j.1007-1334.2019.10.019

Poolsup, N., Suthisisang, C., Prathanturarug, S., Asawamekin, A., and Chanchareon, U. (2004). Andrographis Paniculata in the Symptomatic Treatment of Uncomplicated Upper Respiratory Tract Infection: Systematic Review of Randomized Controlled Trials. J. Clin. Pharm. Ther. 29 (1), 37-45. doi:10.1046/j.1365-2710.2003.00534.x
Shen, M. L., Zhai, S. K., Chen, H. L., Luo, Y. D., Tu, G. R., and Ou, D. W. (1991). Immunomopharmacological Effects of Polysaccharides from Acanthopanax Senticosus on Experimental Animals. Int. J. Immunopharmacol 13 (5), 549-554. doi:10.1016/0192-0561(91)90075-i

Shen, Y. (2017). Response Surface Methodology to Optimize the Extraction Process of Acanthopanax Senticosus Polysaccharide. Heilongiiang Med. Pharm. 40 (03), 75-77.

Sun, D., Chen, J., Hu, H., Lin, S., Jin, L., Luo, L., et al. (2019). Acanthopanax Senticosus Polysaccharide Suppressing Proliferation and Metastasis of the Human Non-small Cell Lung Cancer NCI-H520 Cells Is Associated with Wnt/ $\beta$-Catenin Signaling. Neoplasma 66 (4), 555-563. doi:10.4149/ neo_2018_180913N689

Sun, S. K., Song, T., and Sun, Y. (2018). Immunomodulatory Effects of Acanthopanax Senticosus Acidic Polysaccharides in CyclophosphamideInduced Immunocompromised Mice. Immunological J. 34 (10), 863-868. doi:10.13431/j.cnki.immunol.j.20180133

Tong, L. (1994). Experimental Study on the Anti-tumor Effect and Mechanism of Acanthopanax Senticosus Polysaccharide. Chin. Pharmacol. Bull. 10 (2), 105-109.

Wang, F. F. (2006). Study on the Structure and Chemical Modification of Acanthopanax Senticosus Polysaccharide. Qingdao, China: Ocean University of China.

Wang, H., Sun, B., Zhang, Z., Chen, J., Hao, Q., Sun, Y., et al. (2016). Effects of Acanthopanax Senticosus Polysaccharide on the Proliferation, Apoptosis and Cell Cycle in Human HepG2 Cells. Pharmazie 71 (4), 201-204. doi:10.1691/ ph.2016.5807

Wang, J., Li, G., Yu, L., Mo, T., Wu, Q., and Zhou, Z. (2018). Aidi Injection Plus Platinum-Based Chemotherapy for Stage IIIB/IV Non-small Cell Lung Cancer: A Meta-Analysis of 42 RCTs Following the PRISMA Guidelines. J. Ethnopharmacol 221, 137-150. doi:10.1016/j.jep.2018.04.013

Wang, J. P. (2009). Comparison of Different Methods for Removal of Protein from Extracted Polysaccharide of Acanthopanax Senticosus. NATURAL PRODUCT. RESEARCH DEVELOPMENT 21 (01), 155-158+162. doi:10.3969/j.issn.10016880.2009 .01 .036

Wang, Z. Z. (1986a).Immune Active Polysaccharides of Acanthopanax Senticosus. Shanghai, China: Foreign Medicine. Pharmacy Section, 309.

Wang, Z. Z. (1986b). Immunologically Active Polysaccharide from Acanthopanax Senticosus. Foreign Med. Sci. Sec Pharm. 24 (11), 309.

Wei, X. J. (2018). Optimization of Supercritical CO_2 Fluid Extraction of Kudingcha Polysaccharides. Guangxi Plant 38 (05), 590-595. doi:10.11931/ guihaia.gxzw201706021

Xie, S. S. (1989). Immunoregulatory Effect of Polysaccharide of Acanthopanax Senticosus (PAS). I. Immunological Mechanism of PAS against Cancer. Zhonghua Zhong Liu Za Zhi 11 (5), 338-340.

Xie, S. S. (1989). Effect of Acanthopanax Senticosus Polysaccharide on Immune Function Reconstruction in Mice with Allogeneic Bone Marrow Transplantation. J. Beijing Med. Univ. (04), 289-291.

Xie, S. S. (1989). Experimental Study on the Immunomodulatory Effects of Acanthopanax Senticosus Polysaccharides-I. A Preliminary Study on the Anti-tumor Mechanism of Acanthopanax Senticosus Polysaccharides. Chin. J. Oncol. (05), 338-340.

Xie, Y., Zhang, B., and Zhang, Y. (2015). Protective Effects of Acanthopanax Polysaccharides on Cerebral Ischemia-Reperfusion Injury and its Mechanisms. Int. J. Biol. Macromol 72, 946-950. doi:10.1016/j.ijbiomac.2014.09.055

Xu, F., Zhao, J. Y., and Liu, T. S. (2005). Study on Anti-fatigue Function of Acanthopanax Senticosus Extract. FOOD SCIENCE 26 (9), 453-456. doi:10.3321/j.issn:1002-6630.2005.09.120

$\mathrm{Xu}$, R. S. (1983). Study on the Components of Acanthopanax Senticosus Polysaccharide. Chin. Sci. Bull. (03), 185-187.

Xu, S. K. (1990). Effect of Acanthopanax Senticosus Polysaccharide (ASPS) on Immune Function of Mice. Chin. patent Med. (03), 25-26.

Yang, J. C., Liu, J. S., and Xu, H. Z. (1983). The Effect of Acanthopanax Senticosus Polysaccharide and Sodium Carboxymethyl Starch on the Induction of Interferon in S_(801) and S_(7811) Cell Lines. J. Suzhou Med. Coll. (03), 8-10.

Yang, J. C., Liu, J. S., and Xu, H. Z. (1985). The Effect of Acanthopanax Senticosus Polysaccharide on the Induction of Interferon in S_(801) and S_(7811) Leukemia Cell Lines. Traditional Chin. Med. Inf. (02), 36.

Yang, X. D. (2016). Protective Effects of Acanthopanax Senticosus Polysaccharide on Immune Liver Injury in Mice. Harbin, China: Heilongjiang University of Traditional Chinese Medicine. 
Yin, C., Fan, X., Fan, Z., Shi, D., and Gao, H. (2018). Optimization of EnzymesMicrowave-Ultrasound Assisted Extraction of Lentinus Edodes Polysaccharides and Determination of its Antioxidant Activity. Int. J. Biol. Macromol 111, 446-454. doi:10.1016/j.ijbiomac.2018.01.007

Yu, M. (2019). Reaserch on Extraction Technology of Polysaccharides from Acanthopanax Senticosus Waste Residue by Response Surface Methodology. Chin. Traditional Herbal Drugs 50 (07), 1610-1613. doi:10.7501/j.issn.0253-2670.2019.07.017

Yu, Y., Shen, M., Song, Q., and Xie, J. (2018). Biological Activities and Pharmaceutical Applications of Polysaccharide from Natural Resources: A Review. Carbohydr. Polym. 183, 91-101. doi:10.1016/j.carbpol.2017.12.009

Zeng, P., Li, J., Chen, Y., and Zhang, L. (2019). The Structures and Biological Functions of Polysaccharides from Traditional Chinese Herbs. Prog. Mol. Biol. Transl Sci. 163, 423-444. doi:10.1016/bs.pmbts.2019.03.003

Zhai, S. P. (2007). Optimization and Establishment of the Extraction Process of Acanthopanax Senticosus and Pleurotus Ostreatus Polysaccharides. Shijiazhuang, China: Hebei Normal University.

Zhai, X. N. (2020). Effect of Acanthopanax Senticosus Polysaccharide on Immune Function of Mice. Traditional Chin. Med. Inf. 37 (06), 42-45. doi:10.19656/ j.cnki.1002-2406.200158

Zhang, H., Wang, S., and Jin, L. H. (2020). Acanthopanax Senticosus Polysaccharide Regulates the Intestinal Homeostasis Disruption Induced by Toxic Chemicals in Drosophila. Phytother Res. 34 (1), 193-200. doi:10.1002/ptr.6522

Zhang, J. Y. (2001). Experimental Intervention Effect of Acanthopanax Senticosus Polysaccharide on Lewis Lung Cancer in Mice. CARCINOGENESIS, TERATOGENESIS AND MUTAGENESIS (04), 270. doi:10.3969/j.issn.1004616X.2001.04.109

Zhang, L. P., Zhang, L. Y., and Zhang, Y. K. (1993). Study on the Water-Soluble Polysaccharide of Acanthopanax Senticosus - - The Separation, Purification and Structure of AS-2. J. Biol. Chem. (01), 1-5.

Zhang, N., Zhao, L. Y., Mao, D., Du, Z. Y., Zhang, X. J., Zhai, X. N., et al. (2019). Modulation Effect of Acanthopanax Senticosus Polysaccharides through Inflammatory Cytokines in Protecting Immunological Liver-Injured Mice. Zhongguo Zhong Yao Za Zhi 44 (14), 2947-2952. doi:10.19540/j.cnki.cjcmm.20190129.001

Zhang, N. (2018). Modulation of Acanthopanax Senticosus Polysaccharides on Expression of IL-2,IL-4, INF- $\gamma$ Cytokines, and mRNA in BALB/c Immunological Liver-Injured Mice. Drug Eval. Res. 41 (04), 557-561. doi:10.7501/j.issn.1674-6376.2018.04.010

Zhang, N. (2015). Study on the Immune Regulation of Acanthopanax Senticosus Polysaccharide and its Protective Effect on Immune Liver Injury. Harbin, China: Heilongjiang University of Traditional Chinese Medicine.

Zhang, N. Z., Zhang, W. Z., and Chen, X. J. (1997). Pathological Study of the Influence of Acanthopanax Senticosus Polysaccharide and GST on Experimental Liver Cancer. Cancer Res. (02), 78-80.
Zhang, R., Lv, C., and Lu, J. (2020). Studies on Laccase Mediated Conversion of Lignin from Ginseng Residues for the Production of Sugars. Bioresour. Technol. 317, 123945. doi:10.1016/j.biortech.2020.123945

Zhang, X. F., and Guo, Q. T. (2015). Optimization of Microwave Extraction Technology for Acanthopanax Senticosus Polysaccharide by Box-Behnken Response Surface Methodology. China Pharmacist 18 (09), 1502-1505. doi:10.3969/j.issn.1008-049X.2015.09.022

Zhang, Y. M., and Sun, T. (2005). Comparative Study on Content Determination of Acanthopanax Senticosus Polysaccharide by Different Dry Methods. HEILONGJIANG MEDICINE JOURNAL (03), 160-162. doi:10.3969/ j.issn.1006-2882.2005.03.003

Zhao, J. X. (2008). Acanthopanax Senticosus Polysaccharide's Inhibitory and Immunomodulatory Effects on Human Small Cell Lung Cancer H446 Cells. Shijiazhuang, China: Hebei Medical University.

Zhao, J. X. (2010). ASPS Induces G_2/M Arrest of H446 Cells by Activation of ERK Signal Pathway. BASIC CLINICAL MEDICINE 30 (01), 59-62.

Zhao, J. X. (2008). Induces Apoptosis of Acanthopanax Senticosus Polysaccharides on H446 Cells. CHINESE JOURNAL CELL BIOLOGY (02), 239-242. doi:10.3969/j.issn.1674-7666.2008.02.021

Zhou, L. (2018). Active Ingredients, Pharmacological Actions, and Clinical Applications of Acanthopanax Senticosus in the Central Nervous System. J. Traditional Chin. Med. Univ. Hunan 38 (8), 961-964. doi:10.3969/ j.issn.1674-070X.2018.08.028

Zhu, Q., Tu, G. R., and Shen, M. L. (1982). Effects of Acanthopanax Senticosus Polysaccharides on Specific Antibodies in Mouse Serum. Chin. Pharm. J. (03), 50 .

Conflict of Interest: The authors declare that the research was conducted in the absence of any commercial or financial relationships that could be construed as a potential conflict of interest.

Publisher's Note: All claims expressed in this article are solely those of the authors and do not necessarily represent those of their affiliated organizations, or those of the publisher, the editors and the reviewers. Any product that may be evaluated in this article, or claim that may be made by its manufacturer, is not guaranteed or endorsed by the publisher.

Copyright (c) $2021 \mathrm{Li}$, Chen, Leng and Qu. This is an open-access article distributed under the terms of the Creative Commons Attribution License (CC BY). The use, distribution or reproduction in other forums is permitted, provided the original author(s) and the copyright owner(s) are credited and that the original publication in this journal is cited, in accordance with accepted academic practice. No use, distribution or reproduction is permitted which does not comply with these terms. 


\section{GLOSSARY}

AchE acetylcholinesterase

AG arabinogalactans

ALP Alkaline phosphatase

ALT alanine aminotransferase

AST aspartate aminotransferase

Ara arabinose

ChAT choline acetyl-transferase

ConA Concanavalin A

CVD cardiovascular disease

CTX cyclophosphamide

EGFR epidermal growth factor receptor

ERK regulated protein kinase

ESPS Eleutherococcus senticosus polysaccharides

Fuc fucose

Fru fructose

FT-IR Fourier transform infrared spectroscopy

Gal galactose

GC gas chromatography

Glc glucose

GalA galacturonic acid

GlcA glucuronic acid

GSH glutathione

GSH-Px glutathione peroxidase

HPLC high-performance liquid chromatography

i.g. intragastric administration

i.v. intravenous injection

i.p. intraperitoneal injection

IFN interferon

ICAM intercellular adhesion molecule

iNOS inducible nitric oxide synthase

IL interleukin

JNK c-jun N-terminal kinase
LAK lymphokine-activated killer cell

LC liquid chromatography

LC Lung cancer

LPS lipopolysaccharide

Man mannose

MAPK mitogen-activated protein kinase

MDA malonaldehyde

MMP mitochondrial membrane potential

MS mass spectrometry

NF-кB nuclear factor-kappa B

NSCLC non-small cell lung cancer

NMR nuclear magnetic resonance

NO nitric oxide

OGG1 8-hydroxyguanine DNA glycosidase

PLT platelets

Rha rhamnose

RBC red blood cells

RG rhamnogalacturonan

Rib ribose

SCLC small cell lung cancer

s.c. subcutaneous injection

SFE supercritical fluid extraction

SOD superoxide dismutase

TBARS thiobarbituric acid reactive substances

TCA trichloroacetic acid

TLR toll-like receptor

TC serum total cholesterol

TG triglyceride

TNF tumor necrosis factor

UAE ultrasound-assisted extraction

WBS white blood cells

XGA xylogalacturonan

Xyl xylose. 